\title{
Grupos familiares y redes sociales en la carrera militar. Los oficiales de origen vasco y navarro en el ejército y la marina, 1700-1808
}

\author{
José María Imízcoz Beunza²; Daniel Bermejo Mangas ${ }^{3}$
}

Recibido: 29 de septiembre de 2016 / Aceptado: 28 de foctubre de 2016

Resumen. A lo largo del siglo XVIII, determinadas familias originarias de las provincias vascas y del reino de Navarra tuvieron una presencia destacada en la oficialía del ejército y de la marina. Para explicar este fenómeno, hemos explorado su "genealogía social", en particular el ascenso de estos grupos familiares a partir del comercio y de la simple hidalguía colectiva. A continuación, analizamos los mecanismos relacionales que propiciaron la reproducción de estos grupos en la élite militar durante generaciones: su capital relacional, la circulación de apadrinamientos y recomendaciones, y el papel de la familia y de la parentela en la preparación y socialización de sus vástagos en la milicia. Por último, observamos las relaciones personales que los futuros oficiales iban tejiendo a lo largo de sus trayectorias. Dado el ascenso de muchos de ellos a cargos de gobiernos político-militares en la Península y en las Indias, nos interrogamos sobre la funcionalidad de estas amistades para la configuración de las redes de poder de la clase política del Estado borbónico.

Palabras clave: red social; familia; carrera militar; ejército; marina; elites borbónicas; capital relacional; vascos; navarros; XVIII.

\section{[en] Familiar Groups and Social Networks in the Military Career. The Basque and Navarre Army and Navy Officers, 1700-1808}

\footnotetext{
Abstract. During the 18th century, some Basque and Navarre families had a remarkable position within the prestigious officers of the Spanish army and navy. Those military posts were important since they combined not only a military, but also a political status, holding transcendent government events in all over the Spanish empire. A "social genealogy" analysis is developed in the following paper in order to explain how those Basque and Navarre families managed such a social promotion, which rooted in trade activities and in the collective nobility of their homeland. Their "relational capital" is shown in different strategies such as children sponsorship, recommendations or practical formation carried out inside their family networks. The social relations such as decisive friendships formed through the future officers' training, will be also analysed as part of that social capital that seems particularly intriguing to explain the continuity of different generations of those families in the most prestigious posts of the Monarchy.

Keywords: Social Network; Family; Military Career; Army; Navy; Bourbon Elites; Relational Capital; Basque People; Navarre People; $18^{\text {Th }}$ Century.

1 Proyecto de investigación del Ministerio de Economía y Competitividad del Gobierno de España HAR201348901-C6-4-R, "El proceso de la modernidad. Actores, discursos y cambios, de la sociedad tradicional a la revolución liberal, s.XVI-1850”. Años 2014-2017.

2 Universidad del País Vasco. (España)

josemaria.imizcoz@ehu.es

$3 \quad$ Universidad del País Vasco (España)

d_bermejo07@hotmail.com
} 
Sumario. 1. Oficiales vascos y navarros en el ejército borbónico: procedencia y ascenso social. 1.1. Ventajas y atracción de la carrera militar. 1.2. Tipología de las "genealogías sociales" de los oficiales. 1.3. De los negocios mercantiles a la oficialía del ejército y la marina. 1.4. Trayectorias sociales y transformaciones culturales. 2. La reproducción de parentelas en la carrera militar. 2.1. Redes de relaciones, selección y discriminación en el acceso a la oficialía. 3. Las relaciones familiares en la infancia y juventud de los futuros oficiales: cursus educativo y socialización. 3.1. El ejemplo del Seminario de nobles de Vergara: las familias y los alumnos. 3.2. Implicación de los padres y apadrinamiento vs. mérito. 4. Las relaciones personales de los oficiales y la configuración de sus redes sociales. 4.1. Las amistades en la milicia. 4.2. Las relaciones de las élites militares en los círculos cortesanos... 4.3 ....y en los sectores reformistas ilustrados. Anexos

Cómo citar: Imízcoz Beunza, J. M., Bermejo Mangas, D. (2016) Grupos familiares y redes sociales en la carrera militar. Los oficiales de origen vasco y navarro en el ejército y la marina, 1700-1808, en Cuadernos de Historia Moderna 41.2, 497-538.

La presencia de oficiales de origen vasco y navarro en el mando del ejército borbónico a lo largo del siglo XVIII fue destacada, en consonancia con la elevación de una serie de grupos de parentesco provenientes de estos territorios en las instituciones de la monarquía desde el reinado de Felipe V. Más allá de la mera nómina de oficiales superiores de este origen, nos interesa el funcionamiento de unos grupos familiares y de una dinámica de redes sociales que explican aspectos más generales y de mayor calado, relacionados con la selección y la reproducción de las élites militares y políticas de la centuria y, en última instancia, con la formación de la clase política y militar del Estado borbónico

En esta páginas analizaremos, en primer lugar, el origen social de estos oficiales: la atracción de la carrera militar en el siglo XVIII como vía privilegiada de ascenso, los principales tipos de genealogías sociales que llevaron de la nobleza media o de la simple hidalguía universal a la oficialía, no pocas veces a través del enriquecimiento en actividades mercantiles y de prácticas venales, así como las transformaciones culturales que conllevaron, en muchos casos, las trayectorias de las tierras vascas al ejército.

En segundo lugar, observaremos las bases familiares y los mecanismos de apadrinamiento que explican el acceso privilegiado de determinados grupos familiares a la oficialía del ejército, en un contexto de competición muy selectivo, y su capacidad para reproducirse en la élite militar durante varias generaciones.

En tercer lugar, mostraremos el papel central que jugaba la familia y parentela en los primeros pasos de los futuros oficiales, cómo orientaban su carrera desde niños, se ocupaban de sus estudios y los socializaban en sus redes de relaciones en la élite militar.

Por último, analizaremos las relaciones personales que establecían los oficiales tanto dentro como fuera del ejército, en particular sus amistades y afinidades intelectuales, y reflexionaremos sobre la funcionalidad de estas relaciones para configurar las redes de poder de la clase política y militar que se forma con las reformas borbónicas. 


\section{Oficiales vascos y navarros en el ejército borbónico: Procedencia y ascenso social}

Las tablas que damos en anexo recogen a los oficiales naturales de las tres provincias vascas y del reino de Navarra que hemos podido identificar durante el siglo XVIII. ${ }^{4}$ Siendo el número total muy numeroso, hemos seleccionado únicamente los oficiales de mayor graduación: a partir del grado de coronel en el ejército y de capitán de navío en la marina. También, hemos limitado la información al nombre y apellidos del oficial, el lugar y fecha de nacimiento, el grado más elevado que alcanzó, el arma y la fecha de obtención.

En total, contamos 206 oficiales superiores, de los cuales 145 en el ejército y 61 en la armada. De ellos, 71 eran naturales de Navarra, 52 de Vizcaya, 51 de Guipúzcoa y 29 de Álava. La siguiente tabla especifica sus orígenes geográficos.

Tabla 1. Origen de los oficiales superiores del ejército y la marina.

\begin{tabular}{|c|c|c|c|}
\hline Territorio & Ejército & Marina & Total \\
\hline Vizcaya & 32 & 20 & 52 \\
\hline Guipúzcoa & 32 & 19 & 51 \\
\hline Álava & 22 & 7 & 29 \\
\hline Navarra & 57 & 14 & 71 \\
\hline Sin identificar & 2 & 1 & 3 \\
\hline Total & 145 & 61 & 206 \\
\hline
\end{tabular}

Los navarros eran los más numerosos en la oficialía del ejército: 57 , frente a 32 de Vizcaya, 32 de Guipúzcoa y 22 de Álava. Mientras que los naturales de las provincias costeras sobresalían en la marina: 20 vizcaínos, 19 guipuzcoanos, 14 navarros y 7 alaveses.

En cuanto al origen social, se puede observar que hay apellidos que se repiten y que corresponden a hermanos o familiares. Entre ellos Aguirre, Álava, Areízaga, Armendáriz, Carranza, Daoiz, Eguía, Eslava, Gastón, Gaztañeta, González Bassecourt, González de Castejón, Guendica, Hurtado de Amézaga, Idiáquez, Iturriaga, Jáuregui, Mazarredo, Mencos, Mendinueta, Montero, Salaverría, Salazar, Salcedo, Sesma, Urbina, Viana, Zabala o Zaldúa. Esto nos pone ante la presencia en la oficialía de grupos de parentesco, algunos de los cuales analizaremos cualitativamente más adelante.

Faltan en la nómina los abundantes oficiales hijos de naturales de las provincias cuyos padres se habían establecido en la corte, en Cádiz o en otras ciudades de la Península y de las Indias. Lo observaremos con ejemplos como el de los gaditanos Ruiz de Apodaca Eliza o Gastón de Iriarte Navarrete. Desde nuestra perspectiva, es importante tenerlos en cuenta. De lo contrario, el corte por lugares de nacimiento ocultaría la genealogía social en que se producen las carreras militares, la dinámica histórica, que es lo que nos interesa. Tanto más que estamos ante grupos familiares con una intensa movilidad geográfica.

$4 \quad$ A partir de las bases de datos Fichoz que estamos alimentando en el grupo de investigación. 


\subsection{Ventajas y atracción de la carrera militar}

La carrera militar en el siglo XVIII se hizo especialmente atractiva ${ }^{5}$ y se convirtió en un poderoso imán para las familias que reunían las condiciones para acceder a ella. El empleo en la oficialía procuraba, en primer lugar, sustento económico y seguridad profesional. Las reformas borbónicas del ejército y la marina culminaron el proceso de profesionalización iniciado anteriormente, asegurando empleo y sueldo, con un escalafón de ascensos bien reglado que comenzaba en la adolescencia, con el ingreso en la oficialía como cadetes, y terminaba con la jubilación.

El sustento económico aumentaba conforme se ascendía en el escalafón y comportaba, además, otras seguridades económicas para la familia del militar, como pensiones de viudedad, montepíos para huérfanos, o las posibilidades de recibir becas para sufragar los estudios de los hijos. Así lo muestran algunos ejemplos de asistencia a las familias de oficiales que atravesaban por dificultades económicas. Joaquín Vivanco Yun, capitán de artillería que había ingresado en el cuerpo en 1800, se hallaba enfermo. Su sueldo era el apoyo de su madre viuda y de cinco hermanos. La madre escribe pidiendo que se le pagaran los sueldos atrasados para salir de la miseria. En vista de los méritos de su padre, tío y hermano, se le retira del servicio con una pensión anual. ${ }^{6}$ El joven Felipe Tavira Acosta fue becado por el rey en 1815 para poder estudiar en el Seminario de Vergara y en la Academia de Artillería en 1822, en atención a la situación de su madre, viuda con nueve hijos, y a los méritos de servicio de una serie de parientes y de su propio padre. Lograría alcanzar el grado de subteniente de artillería y capitán de infantería. ${ }^{7}$ Igualmente, Eustaquio Iribarren Ulzurrun, navarro nacido en 1802, consiguió una beca del rey para costear sus estudios. Entró en el Seminario de Vergara gracias a las gestiones de su tío. La madre se hallaba viuda y a "corto de medios", por lo cual el rey mandó que fueran satisfechos todos los gastos de su estancia allí. Alcanzó el grado de coronel de infantería. ${ }^{8} \mathrm{La}$ viuda de Bernardo Guendulain, brigadier de infantería muerto en 1828 , solicita así mismo al rey una pensión para poder pagar la educación de su hijo, en atención a los méritos de su marido. ${ }^{9}$

"La carrera de las armas era de las más cualificadas para ascender en el cursus del honor y en el del prestigio social". ${ }^{10}$ Aportaba honores y privilegios. El fuero y los privilegios militares se ampliaron, con exenciones judiciales, fiscales y de cargas y oficios concejiles. El servicio de las armas se vio recompensado por el rey con honores especiales. De hecho, en 1771 se creó la Orden de Carlos III para premiar especialmente los servicios militares y administrativos al Estado. Entre 1700 y 1808 , los militares destacaron entre los 591 caballeros vascos y navarros distinguidos con hábitos de Órdenes Militares y cruces de Carlos III: 220 individuos que representaban el $37 \%$ de los caballeros, de los cuales 175 cursaron carreras en el ejército (29\%)

\footnotetext{
Martínez Ruiz, E.: "El largo ocaso del ejército español de la Ilustración: reflexiones en torno a una secuencia temporal", Revista de Historia moderna: Anales de la Universidad de Alicante, 22 (2004), pp. 431-452.

Archivo General Militar de Segovia (AGMS), leg. B-2260.

AGMS, leg. T-11.

AGMS, leg. I-489.

AGMS, leg. G-4284, exp. 02.

10 Andújar Castillo, F.: "La carrera militar en la España del siglo XVIII", en Dedieu, J.-P. y Vincent, B. (coords.): L'Espagne, l'Etat, les Lumières. Mélanges en l'honneur de Didier Ozanam, Casa de VelázquezMaison des Pays Ibériques, 2004, p.191.
} 
y 45 en la marina (8\%). ${ }^{11}$ Los honores y privilegios concedidos por el rey podían alcanzar cotas mayores en la cúspide, como muestra el ejemplo de los generales que consiguieron títulos nobiliarios de consideración, incluso la grandeza de España. ${ }^{12}$

La carrera en la oficialía podía llevar a ejercer cargos de gobierno de máximo relieve. A partir del empleo de coronel, la carrera ofrecía tres posibilidades de trayectoria: mantener un perfil plenamente militar, pasar a ocupar cargos político-militares, o ejercer empleos ajenos a la milicia como embajadas, consejos o secretarías del despacho. ${ }^{13}$ Tras ascender en el escalafón, el generalato llevaba a ocupar altos cargos de gobierno político-militares (comandancias, capitanías generales o gobernaciones y virreinatos en Indias), con el poder y prestigio que esto suponía. Por esta vía, los oficiales de más alta graduación se convirtieron en un instrumento decisivo del gobierno político de la monarquía. ${ }^{14}$ Esta tendencia fue tanto más fuerte que una buena parte de los gobiernos territoriales se militarizaron, especialmente los de los reinos de la Corona de Aragón, tras la Nueva Planta, con capitanes generales, intendentes de ejército y corregidores seleccionados entre los mandos miliares por la Secretaría del despacho de Guerra. ${ }^{15}$

Ser oficial del rey tuvo un prestigio añadido en el siglo XVIII. Seleccionados, formados y promovidos por el monarca, los oficiales del ejército borbónico tenían una vinculación especial con el soberano, a través de las academias militares y de las Secretarías de Guerra y de Marina, que seleccionaban, nombraban y promovían a los oficiales, según criterios de mérito, obediencia y servicio, en el marco de una carrera reglada. La correspondencia epistolar de estos oficiales muestra el gran orgullo que experimentaban cuando ascendían en la jerarquía militar y cuando recibían del rey cargos de gobierno, como reconocimiento de unos méritos y prueba de merecer la confianza del monarca. Estos nombramientos se publicaban en la Gaceta de Madrid, órgano de información de la corona a partir de 1762, que hacía llegar la elevación de los agraciados a las élites políticas y económicas de todo el imperio, al menos a los sectores de las élites especialmente conectados con la corona a través de la Gaceta.

Por último, la carrera militar tuvo prestigio intelectual en los círculos más modernizantes del país. El ejército se hizo más técnico y fue un foco principal de desarrollo científico, sobre todo en las "armas sabias" de ingenieros militares, artillería y marina. ${ }^{16} \mathrm{~A}$ lo largo de la centuria, y especialmente en su segunda mitad, fue un semillero de científicos, pensadores reformistas y gobernantes ilustrados, convencidos de su utilidad pública para la nación, y todo ello supuso también un elemento de prestigio intelectual en los círculos ilustrados. De hecho, fue destacada la participación de militares en las sociedades económicas y en el mundo de la cultura. ${ }^{17}$ En el caso de los

11 Aranburuzabala Ortíz de Zárate, Y.: "Caballeros de las Órdenes Militares en Álava, Bizkaia, Gipuzkoa y Navarra en el siglo XVIII: procedencia geográfica y aproximación social”, Sancho el Sabio, 30 (2009), pp.11-48

12 AndúJar Castillo, op. cit. (nota 10), p. 206.

13 Ibidem, p. 203

14 Andúuar Castillo, F: Los militares en la España del siglo XVIII. Un estudio social, Granada, 1991, p. 367; AndúJar Castillo, F.: "Las elites de poder militar en la España borbónica", en Castellano, J. L. (ed.): Sociedad, Administración y poder en la España del Antiguo Régimen, Granada, Universidad de Granada, 1996, p. 234.

15 Dedieu, J.-P.: "La Nueva Planta en su contexto. Las reformas del aparato del Estado en el reinado de Felipe V", Manuscrits, 18 (2000), pp.113-139.

16 Lafuente, A. y Peset, J. L.: "Las actividades e instituciones científicas en la España ilustrada", en SELLÉs, M., Peset, J. L. y Lafuente, A. (comps.): Carlos III y la ciencia de la Ilustración, Madrid, Alianza Editorial, 1987, pp. 29-79.

17 Franco Rubio, G. A.: "Los actores de la sociabilidad ilustrada en España: proyectos y realizaciones", en 
oficiales de origen vasco, el mejor ejemplo es la abundante presencia de militares en las familias dirigentes de la Real Sociedad Bascongada de Amigos del País. ${ }^{18}$

\subsection{Tipología de las "genealogías sociales" de los oficiales}

La promoción en la carrera militar dependía de varios factores: los años de servicio; la participación en espacios privilegiados del aparato militar que procuraban mayor cercanía al rey, en especial las Guardias Reales, semillero de futuros generales y de gobernantes político-militares; el valor del dinero, a través de la venalidad, y la importancia de las redes de poder que articulaban vínculos familiares y amistades. ${ }^{19}$

Nuestra perspectiva relacional y el tipo de fuentes que manejamos nos permiten observar más especialmente dos cosas, la genealogía social de los oficiales, esto es, la dinámica que estuvo en la base de su acceso a la oficialía del ejército, y sus redes sociales, en particular las relaciones que sirvieron tanto para su ingreso y promoción en el ejército como para la reproducción de determinadas parentelas en las carreras militares.

La identidad social de los oficiales se ha solido atribuir genéricamente a "la nobleza". Es cierto que el ingreso en la oficialía del ejército estaba reservado a los nobles. Los candidatos a ser admitidos en las academias militares debían probar orígenes nobiliarios por los cuatro apellidos del demandante. ${ }^{20}$ Sin embargo, esto no debe ocultar la realidad social que se hallaba detrás del estatuto de nobleza. En el caso de los cadetes vascos y navarros, muchos enarbolaban una condición noble que correspondía, en realidad, al estatuto genérico de la hidalguía universal, cuando lo que había detrás, socialmente, eran familias de comerciantes, incluso de puros campesinos. Vizcaya, Guipúzcoa, determinados valles del norte de Álava y del norte de Navarra gozaban de hidalguía colectiva, una ficción de nobleza que no correspondía a condición sociológica alguna, sino al estatuto que unos alodios consiguieron hacer aceptar a la corona en el proceso de formación de la monarquía agregativa. ${ }^{21}$ Luego, los emigrantes de estos territorios supieron sacar partido a esta ventaja extraordinaria. Tradujeron el estatuto colectivo en nobleza familiar y en sus memoriales hincharon el supuesto lustre de su linaje con cargos locales y una retórica más o menos rimbombante. Lo extraño es que los historiadores nos lo hayamos creído.

¿Qué realidad social se ocultaba detrás de esta fachada nobiliaria? ¿Qué genealogía social explica el abundante ascenso de hijos de comerciantes y campesinos a la oficialía del ejército?

Berbesí, L. (coord.): Poder y mentalidades en España e Iberoamérica (siglos XVI-XX): implicaciones y actores. II Seminario Hispano Venezolano, Maracaibo, Universidad de Zulia, 2001, pp. 157-186; García HurTADo, M. R.: El arma de la palabra. Los militares españoles y la cultura escrita en el siglo XVIII (1700-1808), A Coruña, Universidade da Coruña, Servicio de publicaciones, 2002; Agullar PIÑal, F.: Historia literaria de España en el siglo XVIII, Madrid, Editorial Trotta, 1996; Franco Rubio, G. A.: “¿Espada o pluma?, ¿destino militar o puesto administrativo? La incorporación de los militares a las instituciones civiles en a España del siglo XVIII”, Cuadernos de Historia Moderna, 18 (1997), pp.69-86.

18 Imízcoz Beunza, J. M. y Chaparro Sáinz, A.: “Los orígenes sociales de los ilustrados vascos”, en Astigarraga Goenaga, J., López-Cordón, M. V. y Urquía Echave, J. M. (coords.): Ilustración, ilustraciones, San Sebastián, Real Sociedad Bascongada de los Amigos del País, 2009, vol. 2, pp. 993-1028.

19 AndúJar Castillo, op. cit. (nota 10), p. 194.

20 Blas y OsORIO, J. M.: "De las pruebas exigidas para ingresar en las órdenes militares y en la milicia: Real Armada (Compañía de Guardias Marinas) y en los Reales Ejércitos", en VV. AA.: Revista de historia naval, Instituto de Historia y Cultura Naval Armada Española, (1993), pp. 8-9.

21 Imízcoz Beunza, J. M.: "La hidalguía universal vizcaína: intereses políticos y ficciones literarias", en Congreso Interdisciplinar Entre Literatura e Historia: La cultura de la sangre en el Siglo de Oro, Madrid, Universidad Carlos III, 23-24 de septiembre de 2015. 
Atendiendo a su origen social, observamos tres tipos de genealogías. El primero, más tradicional, es el de las familias pertenecientes a la élite provincial. Se trata de familias establecidas en las capitales y villas principales de las provincias que ya formaban parte, desde el siglo anterior, de las familias destacadas de la nobleza provincial, unas parentelas que ya tenían, por lo general, una trayectoria de servicio al rey en la milicia, la administración y el clero desde el siglo XVII. Algunas de estas familias prestaron servicios militares a Felipe V durante la Guerra de Sucesión y aprovecharon el favor del monarca y una coyuntura favorable para elevarse en las Guardias Reales y en otras posiciones destacadas en la corte y en el ejército. Es el caso de los Idiáquez, Aréizaga, Hurtado de Amézaga, Aguirre, Álava, Villarreal de Bérriz, Orbe y Colón de Larreategui. ${ }^{22}$

El segundo tipo de genealogía social es más novedoso y correspondió de forma muy específica al fenómeno de "la hora del XVIII". Se trató del ascenso fulgurante de miembros de pequeñas familias hidalgas que, de la mano de Felipe V, se elevaron con gran fuerza del comercio y el campesinado a carreras de primera fila al servicio del rey. Todos ellos tuvieron en común la voluntad de Felipe V de rodearse de hombres que no tuvieran bases de poder propias, sino que debieran su ascenso al rey, al tiempo que marginaba políticamente a la aristocracia. Como hemos mostrado en otros trabajos, a lo largo del siglo XVIII los valles del norte hidalgo de la montaña de Castilla, de las provincias vascas y del norte de Navarra fueron canteras principales de cuadros de la monarquía borbónica y dieron un número sorprendente de ministros, cargos palatinos, generales, virreyes, obispos, financieros de la corona y grandes comerciantes coloniales. ${ }^{23}$ Numerosos oficiales del ejército y de la marina surgieron de estos grupos familiares. En estos sectores, la movilidad social fue tan rápida que una misma parentela podía incluir todas las clases sociales, de la más baja a la más alta, desde pequeños campesinos y comerciantes, hasta generales y ministros. ${ }^{24}$

Si miramos en la base de la sociedad rural, observamos cómo centenares de jóvenes provenientes de simples casas campesinas hacían "informes de filiación y limpieza de sangre" para acreditar su hidalguía en carreras al servicio del rey. Así lo demuestran los informes que sacaron los mozos naturales o descendientes del Valle de Baztán con el fin de ingresar en los cuerpos militares reservados a la nobleza. Juan José Indaburu Irazábal, natural del lugar de Saldías y residente en Madrid, hizo su informe de filiación en 1774 "para ingresar en el Real Cuerpo de Guardias de Corps". Agustín Ramón Arozarena Arreo, natural de Madrid y descendiente legítimo del lugar de Berroeta, lo sacó en 1778 "para servir en el Cuerpo de Guardias de Corps". Juan Manuel Navarro Barreneche, de Maya, residente en Cartagena de Levante, lo formalizó en 1782 "para ser admitido como cadete de la Compañía de

22 Guerrero Elecalde, R: Las élites vascas y navarras en el gobierno de la Monarquía borbónica. Redes sociales, carreras y hegemonía en el siglo XVIII (1700-1746), Bilbao, Universidad del País Vasco, 2012.

23 Imízcoz Beunza, J. M. y Guerrero Elecalde, R.: "Familias en la Monarquía. La política familiar de las élites vasco-navarras en el Imperio de los Borbones”, en Imízcoz, J. M. (dir.): Casa, familia y sociedad. País Vasco, España y América, siglos XV-XIX, Bilbao, Universidad del País Vasco, 2004, pp. 177-238; DedIEU, J.P.: "Dinastía y elites de poder en el reinado de Felipe V", en Fernández Albaladejo, P. (ed.): Los Borbones. Dinastía y memoria de nación en la España del siglo XVIII, Madrid, Marcial Pons, Casa de Velázquez, 2001, pp. 381-399

24 Imizcoz Beunza, J. M.: "El león, el raposo y los tigres. Transformaciones de la jerarquía política y social en la monarquía española del siglo XVIII", en Seminario Internacional Mercaderes, juristas y otros "grupos intermedios" en el Sur de Europa y en el espacio atlántico. Siglos XVI-XVIII, Roma, 16 y 17 de septiembre de 2015. 
Caballeros Guardias Marinas". Alejo Inda Irigoyen Ochoa, natural de Pamplona y descendiente de Errazu, lo hizo en 1784 "para tomar los Cordones en uno de los Regimientos de Infantería de Su Majestad". Juan Luis Sarratea Mayora, natural de Ciga y residente en Pamplona, lo sacó en 1788 "para entrar como cadete en el Real Cuerpo de Caballeros y Guardias Marinas". Juan Miguel Asco Merloy, natural de Buenos Aires y descendiente de Maya de Baztán, lo formalizó en 1788 "para obtener plaza de Guardia Marina". ${ }^{25}$ Sobre la base de esta hidalguía universal, un hijo de campesinos apadrinado por parientes establecidos en la corte o en los cuerpos privilegiados del ejército podía llegar a ser general del ejército, virrey en Indias o ministro de Guerra.

Un caso minoritario pero elocuente es el de las familias descendientes de antiguos "parientes mayores", esto es, familias de la primera nobleza del país que, a pesar de la antigüedad y calidad de su linaje nobiliario, habían quedado enclavadas en su terruño, sin conexiones para acceder a este tipo de carreras, hasta que, en un momento dado, emparentan, mediante un enlace matrimonial, con los nuevos grupos cortesanos y, gracias al apadrinamiento de estos, pasan automáticamente a colocar a sus vástagos en altos cargos de la corte y del ejército a los que hasta entonces no habían tenido acceso.

Un buen ejemplo es el de la familia vizcaína Urrutia-Las Casas. A lo largo del siglo XVII, los Urrutia de Avellaneda habían sobrevivido en su torre, con las pequeñas rentas que producían las caserías y tierras del entorno, hasta que, en 1736, entró por matrimonio Agustina Las Casas y La Cuadra, hija de una familia de la parentela de Sebastián de La Cuadra, marqués de Villarías, secretario del despacho de Estado de Felipe V. Automáticamente, cinco hijos varones de este matrimonio ingresaron en carreras de relieve al servicio del rey, cuatro de ellos en el ejército: José Urrutia Las Casas, el más destacado, fue capitán general y comandante general de Artillería; Ramón, capitán e intendente; Juan Manuel, capitán, y Nicolás, coronel de infantería. ${ }^{26}$

Es el caso también de aquellos palacios del valle de Baztán, descendientes de señores de palacio medievales, equivalentes a los parientes mayores de Vizcaya y Guipúzcoa, que se hallaban enclavados en la economía local, sin especial acceso a la corte ni a los ejércitos reales, y que, al casar con hijas del grupo de financieros establecidos en torno a Felipe V, entraron a formar parte de estos grupos de parentesco y a ocupar posiciones destacadas en la corte y en las carreras militares.

\subsection{De los negocios mercantiles a la oficialía del ejército y la marina}

En muchas ocasiones, el ascenso de las villas y del mundo rural hidalgo a la élite militar pasó por el comercio. En estos casos, se trataba de familias que, a lo largo de la segunda mitad del siglo XVII y durante el XVIII, estuvieron muy presentes en el comercio colonial y, no pocas veces, en los negocios de la corte. El enriquecimiento mercantil sirvió para ascender socialmente y acceder a la carrera militar. Unas veces, siguiendo la carrera reglada, que empezaba por el ingreso de los hijos como cadetes en las academias militares; otras por la vía venal.

\footnotetext{
Archivo General de Navarra, sección de Protocolos notariales; Archivo Histórico del Valle de Baztán.

26 Urrutia y Llano, J. M.: La casa Urrutia de Avellaneda y familias enlazadas españolas y americanas (Estudios sobre varios linajes de las Encartaciones del Señorio de Vizcaya), Bilbao, s. e., 1968, pp.12-17.
} 
La genealogía de la familia Ruiz de Apodaca muestra el ascenso, en dos generaciones, desde el mundo rural al comercio y de este a las más elevadas carreras en la oficialía y al ejercicio de gobiernos político-militares. Su ejemplo resume la dinámica que siguieron docenas de familias de hidalgos norteños en el siglo XVIII.

Los Ruiz de Apodaca provenían de una familia del mundo rural alavés que a comienzos del siglo XVIII entró en el comercio colonial de la mano de unos tíos establecidos en Cádiz en la segunda mitad del siglo XVII. En 1668, Andrés y Pedro Martínez de Murguía abandonaron la pequeña aldea de Manurga, llamados por un tío, el capitán Juan Sáenz de Manurga, que ya operaba en el comercio gaditano. En los años 1680 y 1690 prosperaron considerablemente en la actividad mercantil, obtuvieron hábitos de Santiago y ocuparon cargos de relieve en el consulado de comerciantes y en cofradías religiosas de la ciudad. Uno de ellos, Andrés, llamó consigo en 1716 a dos sobrinos, Julián Martínez de Murguía y Tomás Ruiz de Apodaca (Manurga, 1702). Tomás prosperó en los negocios, contrajo matrimonio con Eusebia de Eliza y Lasquetti en 1743, procuró una educación exigente a sus hijos y consiguió colocar a tres de ellos en carreras militares de renombre, en la segunda mitad del XVIII. Sebastián Ruiz de Apodaca Eliza (1747-1818) fue teniente general de la Armada; Vicente (1750-1806), capitán de fragata e intendente de marina, y Juan (1754-1835), virrey capitán general de Nueva España (1816-1821) y conde de Venadito. ${ }^{27}$

También proveniente del comercio, la parentela con apellidos Jáuregui, Aróstegui e Iturrigaray dio varios oficiales, generales y virreyes. Se trataba de familias de comerciantes navarros que crearon y dirigieron la compañía de tabaco de La Habana, en 1740, gracias a las relaciones del círculo de baztaneses en la corte de Felipe V y su capacidad para captar el privilegio político. ${ }^{28}$ Estas familias se vincularon estrechamente en los negocios y cruzaron varios matrimonios entre sí. En la siguiente generación, algunos hijos ingresaron en cuerpos privilegiados del ejército, se elevaron en la carrera, alcanzaron el gobierno de virreinatos en Indias y volvieron a reproducir sus alianzas matrimoniales. El baztanés Agustín Jáuregui y Aldecoa (Lecároz, 1711), fue teniente general (1779) y virrey del Perú (1780-1784). Casó con una hija de Martín de Aróstegui, fundador de la compañía de La Habana. A su vez, casó a una hija suya con José Iturrigaray y Aróstegui, futuro virrey de la Nueva España entre 1802 y 1808, el cual era hijo de José de Iturrigaray, cuñado de Aróstegui y factor de la compañía en Cádiz.

Los Gómez de la Torre eran una familia de comerciantes bilbaínos que, desde la segunda mitad del siglo XVII, prosperaron considerablemente en el comercio de la lana y hierro. En el siglo XVIII, al tiempo que un descendiente continuaba con la casa de comercio, la familia situaba a varios hijos en carreras administrativas y militares al servicio del rey. De los vástagos de Bartolomé Ventura Gómez de la Torre (1678-1767) y María Beatriz de Jarabeitia y Urza, dos siguieron carreras militares: José Nicolás Gómez de la Torre Jarabeitia (Bilbao, 1706) alcanzó el grado de mariscal de campo (1779) y Miguel fue primer teniente de las Reales Guardias Españolas de Infantería, aunque falleció pronto.

Garmendia Arruebarrena, J.: Tomás Ruiz de Apodaca, un comerciante alavés con Indias (1709-1767), Vitoria, Diputación Foral de Álava, 1990; GABriel y RuIZ DE ApodACA, F.: Apuntes biográficos del señor don Juan Ruiz de Apodaca y Eliza, conde de Venadito, Burgos, Librería de José Antonio de Azpiazu, 1849

28 Imízcoz Beunza, J. M. y Guerrero EleCAlde, R.: "Negocios y clientelismo político. Los empresarios norteños en la economía de la monarquía borbónica", en OCAMPO SuÁREZ-VALDÉs, J. (ed.): Empresas y empresarios en el norte de España (siglo XVIII), Gijón, Trea, 2012, pp. 331-362. 
Un hermano de estos, Ventura Francisco Gómez de la Torre y Jarabeitia (Bilbao, 1720) continuó con la casa de comercio, casó con María Francisca de Larrinaga y Arrazola en 1746 y enlazó a su única hija superviviente con Juan Rafael de Mazarredo Salazar de Muñatones, hermano del almirante José de Mazarredo (Bilbao, 1745-Madrid, 1812). Entre sus hijos, Francisco Vicente de Mazarredo Gómez de la Torre (Bilbao, 1772) siguió la carrera militar, aunque se ocupó de comercio. Casó con su prima hermana Juana Josefa de Mazarredo y Moyúa, hija del almirante José de Mazarredo y de María Antonia de Moyúa, y su hijo Manuel de Mazarredo Moyúa fue capitán agregado del regimiento de infantería de Extremadura. ${ }^{29}$

Francisco Andújar ha puesto de relieve la importancia de la venalidad de los cargos en el ejército como vía de ascenso social a lo largo del siglo XVIII, aunque, en nuestro caso, no sabemos qué proporción tuvo con respecto a la vía regular.

La vía venal fue una forma de acceder directamente a la oficialía sin necesidad de pasar por el cursus reglado que empezaba como cadete y exigía un ascenso paulatino en el escalafón. Esta vía resultó especialmente interesante para las familias de comerciantes que buscaban asegurar el ingreso en la oficialía para sus hijos. El Cádiz del comercio colonial fue un foco importante de compradores. Entre los comerciantes gaditanos de origen vasco-navarro que compraron oficialías destacan hombres como José de Cadalso, José Iturrigaray, Juan Domingo Arrambide, Antonio Anuncibay o Santiago de Irissarry y sus hijos. ${ }^{30}$ Así mismo, compraron oficialías para sus vástagos comerciantes vascos y navarros establecidas en otros lugares, como la familia Sesma de Corella (Navarra), los Negrete, vizcaínos instalados en la corte, Francisco de Fagoaga, el banquero de plata más importante de México en el XVIII, que compró oficialías para sus dos hijos, el rico comerciante vitoriano Bartolomé Ortiz de Urbina, también para dos hijos, o los vizcaínos Felipe Isasi y José Ramón Gorordo, entre otros.

Bartolomé José Ortiz de Urbina y Ruiz de Zurbano, acaudalado comerciante de Vitoria y futuro marqués de la Alameda (1761), invirtió parte de su fortuna en la compra de grados militares para dos hijos. A Juan Manuel, su primogénito, le compró en 1735 una compañía en el regimiento de dragones de la reina, a la que posteriormente debió de unir el sueldo y grado de coronel. Al segundo, Luis, le compró primero una compañía de infantería y luego, en 1746, el grado de teniente coronel por 45.000 reales. Ambos cursaron luego exitosas carreras miliares y ejercieron gobiernos político-militares. Juan Manuel Urbina Ortiz de Zárate (Vitoria, 1715) alcanzó el grado de brigadier de dragones (1760) y Luis Francisco Urbina Ortiz de Zárate (Vitoria, 1721) fue teniente general (1776).

Otro caso de compra de oficialías por parte de comerciantes vascos, esta vez de San Sebastián, es el de Santiago Claesens, de una acaudalada familia mercantil de origen holandés, muy implicada en la Real Compañía Guipuzcoana de Caracas, de la cual Santiago fue accionista y su hermano Juan Antonio uno de los directores y principales accionistas. El 24 de septiembre de 1742, Santiago compró la comandancia del segundo batallón del regimiento de infantería de Cataluña, grado al que accedió sin haber ejercido anteriormente ningún servicio en el ejército.

29 Alcorta Ortiz de Zárate, E., La burguesía mercantil en el Bilbao del siglo XVIII. Los Gómez de la Torre y Mazarredo, San Sebastián, Txertoa, 2003; Barbudo Duarte, E: Don José de Mazarredo Salazar Muñatones y Gortázar, Teniente General de la Real Armada, Madrid, s. e., 1945.

30 Andújar Castillo, F: El sonido del dinero. Monarquía, ejército y venalidad en la España del siglo XVIII, Madrid, Marcial Pons Historia, 2004, pp. 237-243, 430-453, 304 ss., 210, 205, 166, 342 y 243-246. 


\subsection{Trayectorias sociales y transformaciones culturales}

Algunas trayectorias revelan una dimensión poco conocida, pero muy significativa en nuestro caso: hasta qué punto estas genealogías sociales fueron muchas veces genealogías culturales, procesos de transformación cultural muy significativos. Así lo muestra la genealogía social del coronel de artillería José de Cadalso.

José de Cadalso (Cádiz, 1741-1782), el militar y brillante escritor gaditano, era nieto de Ignacio de Cadalso y Uribarri, un campesino de una pequeña aldea de Vizcaya, Zamudio, que, como escribe el propio Cadalso en sus Memorias, "se fue al otro mundo sin vestirse a la castellana, ni hablar castellano". ${ }^{31}$ Cuando murió, su viuda contrató a un preceptor de Bilbao para que "enseñara el español a sus muchos hijos", y, con este bagaje, sacó a varios de ellos a hacer carrera al amparo de algún pariente establecido en la generación anterior.

El padre de Cadalso - José Cadalso Vizcarra- y su hermano Diego fueron a Indias con un tío que los inició en el comercio, hizo fortuna y casó en Cádiz con Josefa Vázquez Andrade, con la que tuvo una hija y un hijo, José. Además de sus negocios mercantiles, participó, junto con su hermano Diego, en el establecimiento de "factorías españolas" en el Norte de Europa, un proyecto, según parece, patrocinado por el gobierno de la monarquía, lo que indicaría conexiones políticas de la familia en la corte. De hecho, Campomanes puso al padre de Cadalso como ejemplo de lo útil que podía llegar a ser un hidalgo entrado al servicio de su patria. ${ }^{32}$

En este contexto, José de Cadalso recibió de su familia una educación sobresaliente. Primero en el colegio de Jesuitas de Cádiz, y luego en el prestigioso colegio Louis-le Grand de París (1754-1758) y en el Seminario de Nobles de Madrid (17581760), educación que se completó con diversas estancias en Inglaterra, Francia y Holanda. En 1762, ingresó como cadete en un cuerpo de élite, el regimiento de caballería de Borbón, y en 1764 adquirió el grado de capitán de caballería, al costear cincuenta plazas montadas y equipadas para los regimientos de caballería de Borbón y de Montesa por la elevada cantidad de 150.000 reales provenientes de la herencia paterna. ${ }^{33}$ En 1781 alcanzó el grado de coronel de caballería y falleció en la campaña de Gibraltar en febrero de 1782.

La genealogía social de los Cadalso revela las profundas transformaciones culturales que se produjeron en estos grupos familiares al filo de sus trayectorias del enclavamiento local -de las aldeas y villas norteñas-al comercio, el ejército y otras instituciones de la monarquía universal. ${ }^{34}$

Para muchos vascongados y navarros, el aprendizaje del castellano fue el primer paso necesario. Encontramos testimonios de ello a veces francamente inesperados. Es el caso de Pedro Agustín Girón y las Casas (San Sebastián, 1778-Madrid, 1848), IV marqués de las Amarillas y I duque de Ahumada, destacado representante de la

31 José de Cadalso, Escritos autobiográficos y epistolario. Prólogo, edición y notas de N. Glendinning y N. Harrison, Londres, Támesis Books, 1979; Glendinning, N.: Vida y obra de Cadalso, Madrid, Gredos, 1962.

32 Palacios Fernández, E.: "José Cadalso, lección de vizcainía”, en II Seminario de Historia de la Real Sociedad Bascongada de los Amigos del País, San Sebastián, Real Sociedad Bascongada de los Amigos del País, 1989 , pp.12-17.

33 AndúJar Castillo, op. cit. (nota 30), pp. 240 y 19.

34 Imízcoz Beunza, J. M.: "Entre apertura y enclavamiento. Las redes de los navarros en la primera globalización (1512-1833), Príncipe de Viana, 261 (2015), pp. 137-175; Imízcoz BeunZA, J. M.: "Entre sí. Por una historia social de los procesos de civilización”, en García FERnÁndez, M. y Chacón Jiménez, F. (dirs.): Ciudadanos y familias. Individuo e identidad sociocultural hispana (siglos XVII-XIX), Valladolid, Universidad de Valladolid, 2014. 
aristocracia militar, sobrino de Luis de las Casas Aragorri, gobernador de Cuba y capitán general de Cádiz, y del general Francisco Javier Castaños. Así lo relataba en sus memorias. "Yo, en tanto, pasé los primeros años de mi vida en San Sebastián, mi patria, criado totalmente al estilo del país y casi sin saber otra lengua que el vascuence". Hijo de Isabel Las Casas Aragorri, Pedro Agustín se había criado desde la edad de dos meses con su tío abuelo, D. Juan de Aragorri. Como recoge en sus Recuerdos, a la muerte de éste, en 1783, "fui conducido a Madrid con mi aya, natural de Hendaya, como mi nodriza lo había sido de Zugarramurdi, último lugar de España por la parte de Navarra, criándome así en manos de dos fronterizas" (...) "Cuando llegué a Madrid no entendía una sola palabra de castellano, y no perdono a mi madre que me dejase olvidar el vascuence, mi lengua nativa, que muy poco me hubiera costado el conservar, sabiéndolo muy bien mi madre y toda mi familia materna, pero el deseo de que yo hablase pronto y bien el castellano la llevó a este descuido, si así puede llamarse, que toda mi vida he sentido". ${ }^{35}$ Interesante genealogía cultural del padre del fundador de la mismísima Guardia Civil.

Otro testimonio en el mismo sentido es el que exponía en 1766 el capitán de fragata Santiago Zuloaga, en su Tratado instructivo y práctico de maniobras navales para el uso de los caballeros guardias marinas. Santiago Zuloaga había salido de San Sebastián a la edad de catorce años para servir en "los bajeles de Su Majestad en que han fallecido mis Padres, Tíos, y Parientes", sirviendo "en los diversos empleos de tenientes de fragata, hasta capitanes" y era profesor de maniobras desde 1756. En el prólogo de su tratado reconocía sus dificultades en el idioma castellano y pedía indulgencia al lector:

espero de tu prudencia [lector], que disimularás lo primero, los defectos, que acaso te darán en rostro, del lenguaje Castellano; pues no puedes ignorar que es para mí tan extraño el romance, como para ti el Vascuence, el Hebreo, y el Griego; y hasta que tú sepas dar a luz alguna útil producción en Vascuence, o en otras lenguas, y sin erratas, no tienes derecho a burlarte de las mías en una obra castellana, que no es mi lengua materna, ni fue la primera que me enseñaron en Guipúzcoa. ${ }^{36}$

\section{La reproducción de parentelas en la carrera militar}

Tener relaciones privilegiadas con los mandos del ejército o en la corte fue un factor decisivo para conseguir entrar en la oficialía del ejército. Los cuerpos militares tendían al auto-reclutamiento y a la endogamia, de modo que los generales y oficiales de alta graduación podían fácilmente hacer ingresar en ellos a sus hijos y a jóvenes de su parentela. ${ }^{37}$ También utilizaban su influencia para recomendar a los hijos de sus amistades.

A partir de su entrada en estos cuerpos, las prácticas de reclutamiento y el juego de las redes de relaciones propiciaron la reproducción familiar en la oficialía. Hubo familias que se reprodujeron en ella durante generaciones. Así, los guipuzcoanos

\footnotetext{
35 Amarillas, marqués de las, P. A. Girón.: Recuerdos (1778-1837), edición de F. Suárez y A. M. Berazaluce, Pamplona, Eunsa, 1978, vol. I, p. 63.

36 Zuloaga, S.: Tratado instructivo y práctico de maniobras navales para el uso de los caballeros guardias marinas..., Cádiz, Imprenta de Manuel Espinosa de los Monteros, 1766.

37 AndúJar CASTILlo, op. cit. (nota 14), pp. 226-229.
} 
Idiáquez, los vizcaínos Mazarredo, los navarros Gastón de Iriarte o los gaditanos de origen alavés Ruiz de Apodaca, que se vincularon de forma sostenida a la marina y el ejército, dando durante varias generaciones, a lo largo del siglo XVIII y de la primera mitad del XIX, abuelos, hijos y nietos, o colateralmente, tíos-abuelos, sobrinos y sobrinos-nietos militares. Veamos el ejemplo de estas cuatro parentelas, antes de mostrar el juego de relaciones privilegiadas que estuvieron en la base de esta dinámica de acceso y reproducción en los cuerpos de élite.

Las Guardias del rey fueron a lo largo de la centuria el principal semillero de generales del ejército y de cargos político-militares en la Península y las Indias..$^{38}$ Francisco Andújar y Rafael Guerrero han mostrado la reproducción de los Idiáquez en las Guardias Reales y, de su mano, la elevación de numerosos vascongados en estos cuerpos privilegiados.

La figura de Juan de Idiáquez y Eguía (Azcoitia, 1665- 1736) fue decisiva en los orígenes de esta dinámica. ${ }^{39}$ Tras servir en los tercios de Flandes, hizo una carrera especialmente relevante en la corte de Felipe V. Entre 1704 y 1721 fue sargento mayor de las cuatro compañías que formaban las recién creadas Guardias de Corps, el más prestigioso cuerpo del ejército. Su cargo era especialmente influyente. Le daba gran cercanía al rey, con quien consultaba los nombramientos de los empleos administrativos y técnicos del Estado Mayor de la Guardia. Desde estas posiciones, ascendió rápidamente en el escalafón militar. Fue nombrado teniente general en 1706 y luego capitán general. Por su relación de confianza con la familia real, fue elegido para el gobierno de la casa del infante don Fernando: en 1721 fue nombrado gobernador del nuevo cuarto separado del infante don Fernando, en 1724 ayo del nuevo Príncipe de Asturias, y en 1725 sumiller de Corps del futuro Fernando VI.

En paralelo a sus servicios, el rey le encumbró en la escala de honores de la monarquía, concediéndole, entre otras distinciones, el ducado de Granada de Ega con la grandeza de España de primera clase.

Muerto sin descendencia en 1736, Juan de Idiáquez se volcó especialmente en la promoción de su parentela, que se reprodujo en posiciones destacadas de las Guardias durante varias generaciones $\mathrm{s}^{40}$ (ver diagrama $\mathrm{n}^{\circ} 1$ ). Colocó en ellas a sus dos hermanos: Tomás Idiáquez Eguía fue primer teniente de la compañía española de Guardias de Corps, gobernador de Cádiz y Capitán General de la Costa de Andalucía, y José Idiáquez Eguía, primer teniente en el regimiento de Guardias Españolas de Infantería.

En la misma generación, elevó también a varios primos. Entre ellos, Carlos de Areizaga siguió una carrera meteórica en el ejército y en palacio de la mano de su primo. Este le introdujo en 1721 en el cuarto del infante don Fernando, del que sería gentilhombre de cámara y primer caballerizo. Culminó su carrera militar en 1734 como teniente general y "capitán general de los reales ejércitos".

38 AndúJar Castillo, F: "Elites de poder militar: las Guardias reales en el siglo XVIII", en CaStellano, J. L, Dedieu, J.-P. y LóPEz-Cordón, M. V. (eds.): La pluma, la mitra y la espada. Estudios de historia institucional en la Edad Moderna, Madrid, Marcial Pons, 2000, pp.65-94; AndúJAR CASTILlo, F.: "La Corte y los militares en el siglo XVIII", Estudis. Revista de Historia Moderna, 27 (2001), pp. 211-238.

39 Guerrero Elecalde, R.: Las elites vascas y navarras en el gobierno de la Monarquía borbónica: Redes sociales, carreras y hegemonía en el siglo XVIII (1700-1746), Bilbao, Universidad del País Vasco, 2012.

40 AndúJar CAStillo, F.: "De la periferia a la Corte: la integración de vascos y navarros en los cuerpos de elite del ejército borbónico", en Porres MariJuán, M. R. y Reguera ACEDO, I. (coords): La proyección de la monarquía hispánica en Europa: política, guerra y diplomacia entre los siglos XVI y XVIII, Bilbao, Universidad del País Vasco, 2009, pp. 175-196. 
En la generación siguiente, el apadrinamiento de Juan de Idiáquez se extendió a los hijos de sus hermanos. Introdujo en las Guardias a los tres hijos de su hermano Tomás: Antonio Francisco Idiáquez y Garnica fue el primer cadete de guardias de corps de la compañía española y llegó a teniente general, antes de retirarse para tomar sucesión de la casa familiar. José Idiáquez y Garnica fue cadete de la guardia de corps y primer teniente en el regimiento de guardias españolas de infantería (1717), pero se retiró del servicio en 1720. Joaquín Idiáquez y Garnica ingresó en las guardias de corps y ascendió a coronel de caballería del regimiento del Príncipe en 1727, sucediendo a su tío don Juan en el mando de este regimiento. Luego, un primo de este Joaquín, Juan Ignacio Idiáquez, le sucedió en el mando del mismo regimiento, en 1737, de modo que hasta tres Idiáquez se sucedieron al frente del mismo.

Esta mecánica familiar se reprodujo en la siguiente generación, la de los hijos de sus sobrinos, esto es, sus sobrinos-nietos. Por ejemplo, los cuatro hijos de Antonio Francisco Idiáquez Garnica, heredero del título de duque de Granada Ega, hicieron carrera en el mismo regimiento de caballería del Príncipe: José Idiáquez y Garro llegó en 1747 a coronel de dicho regimiento. Pedro Idiáquez Garro fue capitán de caballería en el mismo. Antonio Idiáquez Garro entró como cadete en dicho regimiento y prosiguió su carrera en las Guardias Españolas de Infantería, donde alcanzó el grado de brigadier y tuvo a su mando el regimiento de infantería de Castilla. Por último, Joaquín Idiáquez Garro fue capitán de caballería y en 1755 exempto de la Guardia de Corps, equivalente al grado de coronel de los reales ejércitos.

El fenómeno tuvo todavía efectos en la generación posterior. Al menos un sobrino de los anteriores cuatro hermanos Idiáquez Garro, José Arteaga Idiáquez, ingresó en 1763 como cadete en el regimiento de Guardias Españolas de Infantería y pasó luego a la compañía española de Guardias de Corps, donde desempeñó un puesto en la plana mayor. Alcanzó el grado de teniente general y estuvo al frente de diversas capitanías generales.

La red de parentesco de Juan de Idiáquez Eguía en las Guardias fue mucho más amplia y tuvo numerosas ramificaciones. Rafael Guerrero ha mostrado en su tesis doctoral la extensa nómina de guipuzcoanos y vizcaínos que entraron y ascendieron en estos cuerpos privilegiados gracias a sus relaciones de parentesco y amistad con don Juan de Idiáquez. ${ }^{41}$ Entre ellos, Gabriel José de Zuloaga y Moyúa, José Martín de Murguía, Luis Arteaga y Basurto, Antonio de Arteaga y Verástegui, Miguel Antonio de Zuaznávar, Pedro Antonio de Atorrasagasti y Sasoeta, José Basilio Aramburu Atorrasagasti (conde de Villafuertes, 1744), Joaquín de Emparan y Azcue, Martín Colón de Larreategui, José Ignacio y Antonio Miguel de Zaldúa y Gamboa, Luis de Guendica y Mendieta, Juan de Ezcoiquiz, Francisco Lucas de Arauna y Mallea, Diego de Barraicúa, los hermanos Hurtado de Amézaga y Unzaga, Bruno Mauricio de Zabala, los Díaz Pimienta o los Salcedo Sierralta. Algunos de ellos lograron ascensos importantes en la jerarquía del ejército, desempeñaron gobiernos políticomilitares en diversos territorios de la monarquía, especialmente en Indias, y dieron lugar a nuevas sagas militares. Esto explica la elevada presencia cualitativa de una buena parte de los oficiales de origen vascongado en el ejército borbónico.

Los Ruiz de Apodaca que hemos visto ascender del comercio al servicio al rey en la marina, ofrecen un buen ejemplo de reproducción familiar en este cuerpo (ver diagrama $\mathrm{n}^{\mathrm{o}} 2$ ). Tres hijos de Tomás Ruiz de Apodaca (Manurga, 1702) y Eusebia

41 Guerrero Elecalde, op. cit. (nota 39). 
de Eliza y Lasquetti siguieron la carrera militar: Sebastián Ruiz de Apodaca Eliza (1747-1818) fue teniente general de la Armada, Vicente (1750-1806) capitán de fragata e intendente de marina, y Juan (1754-1835) virrey de Nueva España (18161821), capitán general de la Armada (1830) y conde de Venadito. Por su parte, una hermana, María Teresa Ruiz de Apodaca Eliza casó con Baltasar de Sesma, capitán de fragata y caballero de Santiago.

En la generación siguiente, varios nietos de Tomás Ruiz de Apodaca siguieron carreras militares y varias nietas casaron con oficiales. De los hijos de Vicente y Antonia Beranguer, José Ruiz de Apodaca Beranguer (1788-1867), llegó a ser teniente general de marina y consejero del Consejo de Estado. Dos hermanas suyas enlazaron con marinos. María Dolores Ruiz de Apodaca Beranguer casó en 1805 con Cosme Damián Churruca Elorza, el héroe de Trafalgar. María Asunción Ruiz de Apodaca Beranguer contrajo matrimonio con Francisco Beranguer, jefe de escuadra. Por otro lado, la hija de Juan Ruiz de Apodaca y de María Rosa Gastón, Ma Dolores Ruiz de Apodaca Gastón de Iriarte, casó con Francisco Javier de Gabriel y Estenoz, brigadier de los reales ejércitos, gobernador militar y político de la plaza de Badajoz y caballero de Alcántara.

En la siguiente generación, las carreras militares se volvieron a repetir, esta vez entre los biznietos de Tomás Ruiz de Apodaca. Entre ellos, José María Beranguer Ruiz de Apodaca fue ministro de marina en 1870, y Fernando Gabriel y Ruiz de Apodaca (Badajoz, 1828-Madrid, 1888) hizo carrera en la artillería y alcanzó el grado de teniente coronel. ${ }^{42}$

La presencia en la marina y el ejército de la parentela del capitán general y ministro de marina José de Mazarredo Gortázar fue especialmente abundante (ver diagrama $n^{\circ} 3$ ). Hasta su figura, la presencia de la familia en la marina había sido escasa. En las generaciones anteriores, un primo de su abuelo materno, Miguel Guendica Palacios, fue capitán de fragata y un primo segundo de su madre, Miguel Guendica Jugo, guardia marina. Estos parientes colaterales no eran muy inmediatos, pero los primeros apadrinamientos de la familia Mazarredo-Gortázar en la marina pudieron arrancar quizás con ellos.

En su generación, José de Mazarredo tuvo siete primos (todos por parte materna) y dos cuñados en la marina y el ejército. Tres primos carnales Gortázar Montiano: Miguel (teniente de navío); José (teniente de fragata) y Juan (teniente coronel de infantería). Dos primos carnales Allende Salazar: Nicolás (teniente de navío) y José (capitán de artillería). Dos primos carnales Larrínaga Gortázar: Francisco (teniente de artillería) y Joaquín (subteniente de artillería). Y dos cuñados: Jean Paul Saint Cricq (teniente coronel) y Roque Moyúa Munibe (capitán).

En la generación siguiente, numerosos sobrinos de Mazarredo siguieron así mismo carreras en la oficialía. Cuatro sobrinos Moyúa Mazarredo (hermanos de su mujer y sobrina): Francisco (capitán de fragata), Ramón (teniente de navío), José (teniente de navío) y Joaquín (teniente de navío). Su sobrino Carlos Saint Cricq Mazarredo (capitán de navío). Tres sobrinos Mazarredo Gómez de la Torre: Francisco (mariscal de campo), José (alférez de navío) y Santiago (teniente de fragata). De esta familia, dos sobrinas Mazarredo Gómez de la Torre casaron con marinos: Antonia, con Manuel Victoria Lecea (capitán de navío) y Joaquina, con José Salazar Allendelagua (capitán de fragata). Otra sobrina de esta misma familia, María Josefa Mazarredo

42 Garmendia Arruebarrena, op. cit. (nota 27), pp. 22, 349, 350. 
Gómez de la Torre, casaba con Pedro Allende Salazar, de una familia que contaba con varios militares, entre tíos, hermanos y cuñados, con apellidos Allende Salazar y Ordóñez Barraicua, estos últimos herederos del marquesado de Villarías.

En la cuarta generación, dos descendientes de José Mazarredo alcanzaban elevados puesto en la marina y la política: Su nieto, Manuel Mazarredo Mazarredo (general liberal, jefe de Estado Mayor, ministro de guerra en 1844 y capitán general de las Vascongadas en 1852-1854) y su sobrino nieto, José Allende Salazar Mazarredo (teniente general y ministro de marina). ${ }^{43}$

Los Gastón de Iriarte revelan un modelo de familia cuya política de colocación de los hijos a los largo de cuatro generaciones, entre 1680 y 1830, consistió en guardar un heredero o heredera como sucesor en la casa troncal y en sacar a los demás hijos varones para que prosperaran en carreras al servicio del rey, gracias al apadrinamiento de los parientes y amigos que se hallaban establecidos en esas carreras y podían favorecerlos. En los años 1680, esta familia de una aldea del Valle de Baztán se incorporó a una dinámica de negocios y carreras en la corte y en la orbe de la monarquía de la mano de su pariente Juan de Goyeneche, financiero de Felipe V, que llevó consigo a varios sobrinos segundos para ayudarle en los negocios.

A partir de ahí, los parientes de cada generación elevados en las carreras de la monarquía fueron apadrinando sistemáticamente a sus sobrinos de la generación siguiente. Tras unos inicios en los negocios, las carreras de los Gastón de Iriarte se concentraron en el ejército y la marina (ver diagrama $\left.n^{\circ} 4\right)$. En la segunda generación, la de los años 1720, dos de los tres hijos varones siguieron carreras militares: Miguel José Gastón de Iriarte Elizacoechea (Errazu, 1716-1797) fue teniente general de la marina y comandante de la Real Compañía de Guardias Marinas de Cádiz, y Pedro José (1718-1789) ingresó en las guardias reales y alcanzó el grado de teniente coronel, antes de retirarse a la sucesión de la casa nativa. Ambos hermanos dieron lugar a sagas militares.

En efecto, en la tercera generación, en la década de 1780, los dos varones de Pedro José salieron de la aldea a cursar carreras militares: Luis Gonzaga Gastón de Iriarte y Cortejarena (1774-1855) en la artillería, llegando al grado de mariscal de campo y su hermano José Joaquín (1766-1823) en las guardias marinas, de las cuales se retiró para volver a casa. En la cuarta generación, ya en el primer tercio del siglo XIX, cuatro hijos de José Joaquín siguieron carreras militares: José Antonio Gastón Dolarea (1788-1813) fue guardia de corps; Miguel José (1791-1837), comandante de artillería; Celestino Javier (1793-1834), capitán de artillería, y Lucas Vicente (17951834), alférez de caballería.

Por su parte, el teniente general Miguel José Gastón de Iriarte y Elizacoechea (Errazu, 1716-1797) dio lugar a una amplia saga de marinos y militares que se reprodujo en estas carreras durante varias generaciones. ${ }^{44}$ Miguel José casó en 1765, en Cartagena de Indias, con Josefa de Navarrete y Lanz, hija del mariscal de campo y capitán general del Yucatán, don Melchor de Navarrete. Sus tres hijos varones siguieron carreras en la marina. Miguel María Gastón de Iriarte y Navarrete (Car-

43 Barbudo Duarte, op. cit. (nota 29). Base de datos Fichoz; VÁlgoma, D.: Real Compañía de Guardias Marinas y Colegio Naval. Catálogo de pruebas de caballeros aspirantes, Madrid, Instituto Histórico de Marina, 19431955, exps. 468, 2018, 2444, 2456.

44 Jaureguizar, marqués de, Francisco Javier Pérez de Rada: Nobiliario de Navarra, Madrid, marqués de Jaureguizar, 1978, pp. 42-48; PAvíA, F. P.: Galería biográfica de los generales de Marina, Madrid, J. López, 1873, pp. 7-14; VÁlgoma, op. cit. (nota 43). 
tagena de Indias, 1765-1839) alcanzó, como su padre, el grado de teniente general, en $1825 .{ }^{45} \mathrm{Su}$ hermano Melchor (Isla de León, 1772) fue teniente de fragata y pasó a desempeñar el cargo de tesorero del ejército y de la Hacienda de La Habana. El tercero, Antonio (Isla de León, 1776) fue capitán de navío.

Los matrimonios de los hijos y de las hijas de Miguel José Gastón de Iriarte se concertaron con familias de marinos o de guardias reales. Su hija María Rosa casó en 1793, en Cádiz, con el capitán de navío Juan José Ruiz de Apodaca y Eliza (Cádiz, 1754-1835), futuro conde de Venadito, miembro de otra importante saga de militares. Melchor casó en 1806, en Cartagena de Indias, con María de Montalvo y Narváez, hija del teniente coronel de los reales ejércitos Rafael de Montalvo. Antonio casó en 1813 con Ana de Ansoátegui y Luque, hija del brigadier de los reales ejércitos Cayetano de Ansoátegui.

En la generación siguiente, varios nietos de Miguel José Gastón de Iriarte continuaron igualmente carreras militares en la Real Armada y en las Guardias Reales. ${ }^{46}$

\subsection{Redes de relaciones, selección y discriminación en el acceso a la oficialía}

La observación de las parentelas que hemos visto reproducirse en la oficialía, como los Idiáquez, Mazarredo, Ruiz de Apodaca o Gastón de Iriarte, muestra que los lazos de familia y parentesco fueron la base más sólida de acceso a la carrera militar. $\mathrm{La}$ capacidad de entrada en ella dependía de la posición y elevación de los parientes patrocinadores. Cuando estos podían, por su cargo, dar entrada a los vástagos de su parentela en un cuerpo de élite que estaba bajo su mando, no era necesario recurrir a otros valedores. En cambio, cuando la familia no tenía un pariente que pudiera procurar directamente el acceso de los suyos a la oficialía, era necesario recurrir a otras relaciones y entrar en el juego de recomendaciones entre amigos.

En otros trabajos hemos documentado ejemplos de cómo funcionaban en la práctica estas redes de relaciones y no es necesario repetirlos aquí. Rafael Guerrero ha mostrado la movilización de sus relaciones en la corte de Felipe $\mathrm{V}$ por los vizcaínos Villarreal de Bérriz para promocionar a su hijo Pedro en las Guardias Reales. Por nuestra parte, hemos observado la capacidad de Miguel José Gastón de Iriarte, teniente general de la Armada (1779), para promocionar a sus hijos y sobrinos en el cuerpo. También hemos analizado la movilización de la red de relaciones del teniente coronel Pedro José Gastón de Iriarte para lograr, en 1789, el ingreso de su hijo Luis Gonzaga en la Academia de artillería de Segovia, en un contexto francamente difícil. Hemos observado así mismo cómo, más allá de las relaciones familiares más inmediatas y operativas, funcionaba un tráfico intenso de recomendaciones con las que los mandos militares eran solicitados por parientes y amigos que recurrían a ellos en favor de sus amistades. Así mismo, pudimos entrever, a través de otros ejemplos, las dificultades para colocar a los hijos en la cerrera militar que se planteaban cuando la familia perdía sus apoyos más inmediatos y se veía obligada a recurrir a recomendaciones más alejadas y menos eficaces.

45 Pavía, op. cit. (nota 44), pp. 11-14.

46 Jaureguizar, op. cit. (nota 44), pp. 44-48; Gabriel y Ruiz de ApodaCA, op. cit. (nota 25). Archivo de la Casa Gastón de Iriarte (ACGI), "Cuadro de los descendientes del E. S. teniente general de la Armada D. Miguel Gastón”, por Pedro de Tavira y Gastón, Madrid, 14 de junio de 1882. 
Para este trabajo, la correspondencia privada se ha revelado una fuente primordial. De otro modo, la percepción de las relaciones de parentesco en el ejército se apoya únicamente en pruebas circunstanciales, en constatar la coincidencia de varios parientes en una misma institución, sin que se pueda demostrar la causalidad efectiva que explica esta presencia ni captar cómo se producía.

Dados el prestigio y los réditos que procuraba, la carrera militar atraía a muchos más aspirantes que plazas disponibles. La selección de candidatos se hacía en un contexto de fuerte competencia entre familias de las élites con ambición de colocar a sus hijos en posiciones ventajosas al servicio del rey. Atribuimos la oficialía a la nobleza, pero esto no basta para explicar quiénes entraban en ella y quiénes no. Todos los candidatos, en principio, reunían la condición noble que se exigía para ingresar en las academias militares y, sin embargo, unos ingresaban en ellas y otros se veían rechazados.

La facilidad o dificultad para ingresar y escalar en la oficialía dependía, claro está, de la coyuntura en la oferta y la demanda de plazas, esto es, del número de plazas disponibles en cada momento. En las décadas finales del siglo, el sistema parece saturado. La demanda se multiplica y los recursos de la gracia real no llegan a cubrirla, en un contexto de dificultades fiscales y de macrocefalia en el ejército, ya de por sí excesiva. La corte de la última década del reinado de Carlos III se veía invadida por una multitud de pretendientes que acudían a ella con sus memoriales para intentar conseguir empleos, lo que obligó al rey a ordenar reiteradas veces su expulsión.

Que los "memoriales" no nos engañen. Los méritos de la familia no valían gran cosa por sí mismos si no se tenían valedores que los hiciera valer, sobre todo cuando sólo había plazas para unos pocos. Por ejemplo, en la promoción en que Luis Gonzaga Gastón de Iriarte entró en la Academia de artillería, en 1789, solamente fueron admitidos once de los ciento cincuenta candidatos que se presentaron, todos ellos nobles sin duda. En "el capital relacional" vimos con detalle la influencia de las relaciones que lo hicieron posible. Son las relaciones efectivas, el capital relacional de la familia, o sea, su poder de influencia, las que determinaban la composición social de la oficialía, y no criterios estamentales genéricos. La cuestión es clave, puesto que de esta discriminación en la base dependía la composición efectiva de la oficialía y, más ampliamente, de la clase política del Estado borbónico.

\section{Las relaciones familiares en la infancia y juventud de los futuros oficiales: cursus educativo y socialización}

Las relaciones familiares estuvieron muy presentes en los orígenes de la carrera militar y fueron particularmente operativas en los primeros años de infancia y juventud de los futuros oficiales. La familia orientaba la trayectoria educativa de sus hijos hasta el ingreso en la oficialía, pero tenía que seguir, en principio, un cursus que se había ido institucionalizando con el tiempo.

En el siglo XVIII, por primera vez, el rey forma a los mandos de su ejército, mediante la creación de las academias militares. ${ }^{47}$ Las más tempranas fueron la Acade-

Dedieu, J.-P.: "La muerte del letrado", en Aranda PÉRez, F. J. (Coord.): Letrados, juristas y burócratas en la España moderna, Cuenca, Ed. de La Universidad de Castilla-La Mancha, 2005, p. 502. 
mia de ingenieros de Barcelona $(1715)^{48}$ y la Academia de Guardiamarinas de Cádiz (1717) En los cuerpos del ejército, los oficiales se formaban como cadetes en los mismos regimientos hasta la creación de academias especializadas durante el reinado de Carlos III, como el Real Colegio de Artillería de Segovia (1764) ${ }^{49}$, la Academia de Caballería en Ocaña (1775) y la Academia de Infantería en Ávila (1774-1776). ${ }^{50}$

La figura del cadete surge en el siglo XVIII como puerta de entrada a la oficialía del ejército para los hijos de la nobleza. Para ocupar plaza de cadete, los pretendientes debían reunir, principalmente, dos condiciones: demostrar su condición noble y asegurarse unas "asistencias" que les permitieran continuar en la oficialía del ejército con el decoro que el cargo requería. ${ }^{51}$ También había requisitos de edad. Los candidatos a ingresar en la Academia de guardias marinas debían tener entre 14 y 18 años. Aunque hubo excepciones, el $72 \%$ de los cadetes vascos y navarros cumplían este requisito. ${ }^{52}$

\subsection{El ejemplo del Seminario de nobles de Vergara: las familias y los alumnos}

Otra condición para ingresar en la Academia de guardias marinas era poseer cierto nivel educativo. Desde su creación en 1726, el Seminario de Nobles de Madrid fue un semillero donde se formaron los hijos de la élite nobiliaria cuyas familias ambicionaban, entre otros, los puestos de mando en el ejército. En 1776, los dirigentes de la Real Sociedad Bascongada de los Amigos del País, cuyas familias estaban especialmente conectadas con elevadas carreras militares, crearon el Real Seminario Patriótico de Vergara, uno de cuyos objetivos era formar a los jóvenes que iban a hacer carrera en la administración real y en los cuerpos militares. La educación se destinaba, de manera genérica, "a (...) facilitar las nociones generales de buena educación", esto es, los saberes y modales que necesitaban los futuros patricios locales, pero también, de manera especial, a "ser un taller adecuado a formar sujetos hábiles para las carreras y profesiones de inmediata utilidad al Estado". ${ }^{33}$ Entre otras ventajas, los estudios en el Seminario de Vergara servían para acumular antigüedad dentro del ejército. ${ }^{54}$

A partir de 1776, el Seminario de nobles de Vergara sobresalió especialmente como centro de preparación de futuros cadetes. El 46\% de los alumnos que pasaron por sus aulas se destinaron a la carrera militar: 244 jóvenes de los 542 que estudiaron en el Seminario, de los cuales 148 fueron al ejército (el 28\%) y 92 a la marina (el $18 \%)^{55}$

48 Galland Seguela, M.: Les ingénieurs militaires espagnols de 1710 à 1803, étude prosopographique et sociale d'un corps d'élite, Madrid, Collection de la bibliothèque de la Casa de Velázquez, 2008.

49 Herrero Fernández-Quesada, M. D.: La enseñanza militar ilustrada. El Real Colegio de Artillería de Segovia. Segovia, BCA, 1990.

50 Herrero Fernández-Quesada, M. D.: "La formación de los militares en el siglo XVIII. El colegio artillero de Segovia o la creación de un modelo", en Imízcoz Beunza, J. M. y Chaparro Sáinz, A. (coords.): Educación, redes y producción de élites en el siglo XVIII, Madrid, Sílex, 2013, pp. 317-336.

51 AndúJAr CASTILlo, op. cit. (nota 14), p.102.

52 Bermejo, D., Esteban, J. y Gorraiz, N.: "Cadetes vascos y navarros en la Academia de Guardias Marinas de Cádiz (1717-1821)”, en Imízcoz Beunza y Chaparro Sáinz, op. cit. (nota 50), pp. 281-316.

53 Chaparro SÁInz, A.: Educarse para servir al Rey: el Real Seminario patriótico de Vergara (1776-1804), Bilbao, Universidad del País Vasco, 2011, pp. 252-253.

54 Chaparro SÁInz, A.: "Del pupitre a la espada: el Real Seminario de Vergara, cantera de militares", Revista de Demografía Histórica, 27-1 (2009), pp. 61 y 71

55 Chaparro Sáinz, op. cit. (nota 53), pp. 29 y 92. 
Tabla 2. Destinos profesionales de los alumnos de Vergara (1776-1804).

\begin{tabular}{|l|c|c|}
\hline Carrera & & $\mathbf{\%}$ \\
\hline Militar & 244 & 46 \\
\hline Ejército & 148 & 28 \\
\hline Marina & 92 & 18 \\
\hline Administración real & 38 & 7 \\
\hline Cargos locales o provinciales & 35 & 6 \\
\hline Otros & 72 & 13 \\
\hline No identificados & 159 & 28 \\
\hline Total & 542 & 100 \\
\hline
\end{tabular}

Álvaro Chaparro ha reconstruido el perfil social de los padres que llevaron a sus hijos al Seminario de Nobles de Vergara. Concretamente, logra identificar el perfil de 220 padres, de los 411 progenitores de los 542 alumnos que fueron al Seminario entre 1776 y 1804 . Gran parte de estas familias pertenecían a un entramado de parentelas bien situadas en las estructuras de la monarquía. De los 220 padres identificados, 126 (el 57\%) seguían carreras al servicio del rey: 61 en el ejército y la marina (el 28\%), 59 en la administración real (el 27\%) y 6 en cargos de palacio. El 81\% de los hijos de militares siguieron, igualmente, la carrera militar, con lo que volvemos a encontrar, a escala más general, la endogamia que hemos observado al tratar de la reproducción de las familias en el ejército y la marina.

En cambio, una minoría de familias parece muy alejada de la esfera de las grandes carreras al servicio del rey, en particular, las familias de comerciantes. De los padres identificados, 36 ejercían el comercio (16\%) y 49 eran patricios con cargos locales y provinciales $(22 \%)$ Para estas familias, Vergara supuso sin duda la posibilidad de insertarse en procesos de ascenso social y, en nuestro caso, de palanca de ascenso del comercio a la carrera militar. ${ }^{56}$

El origen geográfico de los alumnos de Vergara es también significativo para detectar las redes sociales en las que se movían estas familias. De un total de 517 alumnos con el lugar de origen identificado, Álvaro Chaparro ha dado los siguientes resultados:

Tabla 3. Origen geográfico de los alumnos de Vergara (1776-1804).

\begin{tabular}{|l|c|c|}
\hline Origen & Cifra & \% \\
\hline Península & 401 & 77 \\
\hline Indias & 114 & 22 \\
\hline Otros & 2 & \\
\hline Total & 517 & 100 \\
\hline Orígenes principales de la Península & 129 & $\%$ \\
\hline $\begin{array}{l}\text { Provincias vascas } \\
\text { (Guipúzcoa 53, Vizcaya 52, Álava 24) }\end{array}$ & 25 \\
\hline $\begin{array}{l}\text { Regiones limítrofes } \\
\text { (Navarra 34, La Rioja 25, Cantabria 21) }\end{array}$ & 80 & 15 \\
\hline $\begin{array}{l}\text { Andalucía } \\
\text { (provincia de Cádiz 47) }\end{array}$ & 70 & 13,5 \\
\hline
\end{tabular}

56 Chaparro SÁInZ, op. cit. (nota 53), pp. 184-185. 


\begin{tabular}{|l|l|l|}
\hline Madrid & 42 & 8,1 \\
\hline Castilla-León & 29 & 5,6 \\
\hline Galicia & 21 & 4 \\
\hline
\end{tabular}

El resto de los territorios aportan menos de 10 alumnos, destacando las plazas militares de Isla de León (7), El Ferrol (8) y Cartagena (6).

Una cuarta parte de los alumnos provenían de las provincias vascas; con ser el mayor porcentaje, tres cuartas partes venían de otros lugares de la Península y de América. En no pocos casos, se trataba de familias originarias de las provincias que, siguiendo sus negocios y carreras al servicio del rey, se habían afincado en diversas ciudades de la monarquía y, al fundarse el Seminario de Vergara, enviaron a sus hijos allí, con la esperanza de que les sirviera de puerta de entrada en la carrera militar.

En un trabajo anterior pudimos mostrar cómo el reclutamiento, la concentración y la reproducción de grupos familiares en determinadas instituciones se explicaba por una lógica de red social, más que por determinismos geográficos o de otro tipo. ${ }^{57}$ Con el ejemplo de los Gastón de Iriarte, vimos cómo, a partir de un primer contacto personal en la marina, entre Miguel José Gastón de Iriarte y José de Mazarredo, los Gastón se introducen en Vergara y cómo, a partir de ahí, la conexión se extiende de forma significativa en su parentela: Primero, los tres hijos del teniente general, Miguel, Melchor y Antonio Gastón y Navarrete. Luego, el hijo de un hermano, Luis Gonzaga Gastón y Cortejarena; el hijo de una prima carnal, Francisco de Paula Indaburu y Dolarea, y aún en la siguiente generación, un sobrino nieto, Celestino Gastón y Dolarea. La presencia de estos mozos originarios de aldeas del Norte de Navarra no se debe, como podría pensarse, a la proximidad geográfica con Vergara o a otro determinismo semejante, sino a una conexión que se produce en Cádiz, en la carrera militar, entre dos personas que conectan esferas sociales que hasta entonces estaban separadas y que, de no darse esta conexión, probablemente hubieran seguido estándolo.

Algo semejante podemos sugerir a propósito del origen geográfico de los cadetes vascos y navarros de la Academia de guardias marinas. ${ }^{58}$ Entre 1717 y 1821 ingresaron 289 cadetes vasco-navarros, de los cuales 113 guipuzcoanos, 86 vizcaínos, 24 alaveses y 66 navarros. Representaban el 7,2\% del total de 4.015 guardias marinas, un porcentaje comparativamente elevado, habida cuenta de la débil población de estas provincias. Junto a ellos, habría que tener en cuenta a otros 204 cadetes originarios de dichos territorios, fruto de la gran movilidad geográfica que caracterizaba a estos grupos de parentesco.

En toda lógica, predominaban claramente las capitales, Bilbao y San Sebastián, seguidas por Vitoria y Pamplona, y algunas villas costeras, pero también estaban bien representadas villas del interior como Azpeitia, Tolosa y Azcoitia. Por ejemplo, la quinta población en número era Corella, una villa navarra de tierra adentro, y esta presencia parece corresponder a la red de la familia Sesma: ocho guardias marinas naturales de Corella llevaban el apellido Sesma. Es probable que procedieran de las ramificaciones de la familia Sesma que se elevó en las finanzas reales durante el reinado de Felipe V. ${ }^{59}$

Imízcoz Beunza, J. M.: "Militares ilustrados: parentesco, amistad y afinidades políticas en la formación de "élites estatales" en el siglo XVIII, en García Hurtado, M. R. (coord.): Soldados de la Ilustración. El ejército español en el siglo XVIII, A Coruña, Universidade da Coruña, 2012, pp. 165-214

58 Bermejo, Esteban y Gorraiz, op. cit. (nota 51); GonzÁlez-Ripoll NaVArro, M. D.: Bajo pólvora y estrellas. Churruca y otros marinos vascos de la Ilustración, Donostia-San Sebastián, Museo Naval, 2000, p. 35.

59 Eran Miguel Sesma Escudero (ingresa en 1730), Fernando Sesma Gorraiz (1755), Fermín Sesma Payán (1760), 
También, los guardiamarinas provenientes de pequeñas aldeas del Norte de Navarra sugieren que eran el fruto directo de determinadas redes de parentesco. Así ocurre con los apellidos Uztáriz ${ }^{60}$, Gastón de Iriarte ${ }^{61}$, Micheo $^{62}$, cuyos apadrinamientos y penetración en las instituciones de la monarquía conocemos de primera mano. Hay otros que, aunque no tuvieran parentesco inmediato con los anteriores, estuvieron sin duda en su círculo de relaciones, como sugieren las conexiones de los Mendinueta o los Borda con los Gastón de Iriarte. ${ }^{63}$

La presencia de guardiamarinas procedentes de villas y aldeas del interior muestra la insuficiencia de las explicaciones deterministas y confirma la necesidad de investigar las redes sociales a través de las cuales se producía la entrada en la élite militar. También, en el caso de las capitales y de las villas costeras, hay que ir más allá del determinismo geográfico y explicar porqué determinados individuos sí y otros no: esto es, la diferencia social entre unos y otros en el acceso o no a posiciones privilegiadas, en función de las conexiones que se tuvieran o no con determinadas redes de poder.

\subsection{Implicación de los padres y apadrinamiento vs. mérito}

Como hemos dicho, las relaciones familiares fueron especialmente decisivas en los primeros años de infancia y juventud de los futuros oficiales. La correspondencia epistolar que se conserva en el archivo municipal de Vergara, por ejemplo, revela la implicación de los padres y madres de los alumnos en la educación de sus hijos. En sus cartas destacan las referencias al comportamiento, la salud y la educación de los niños: su estado de salud, la conducta en las clases, la actitud con los profesores y el resto de compañeros, y los resultados de los exámenes.

Se ve cómo los padres orientaban los estudios de sus hijos en función de las carreras a las que los destinaban, más allá del programa académico general. Aquellos que conducían a sus hijos hacia la carrera militar pedían que se les aplicara especialmente a las matemáticas, "dejando de gastar así el tiempo en la gramática latina". También "al dibujo, por lo esencial que es para un militar, y lo mismo a la geografía". $\mathrm{O}$ a la lengua francesa e inglesa, así como al baile y a la esgrima, pide desde La Habana el militar Vicente Rizel, en 1788, para sus dos hijos, que seguirán la carrera en la Artillería. La "lengua francesa y otras habilidades (...) que le facilite la estimación y aprecio entre gentes". En cualquier caso, que se hagan hombres útiles "y por esto capaces de adquirir la estimación de sus jefes o sujetos que traten".

Cada cuatrimestre, las familias recibían del Seminario las notas de sus hijos en conducta, aplicación y aprovechamiento, y los padres respondían celebrando los resultados y dando "mis gracias por el cuidado que le ha debido y por las noticias de

Leandro Sesma Biota (1761), Alberto Sesma Escribano (1773), José Vertizverea Sesma (1785) Luis Sesma San Juan (1792) y José Sesma San Juan (1795).

60 José Azcárate Uztáriz (Pamplona) (ingresa en 1741), Juan Endara Uztáriz (Lesaca) (1775), los hermanos Martínez Elizalde Uztáriz (Zuasti) (1770) y Juan Juan José Martínez Elizalde Uztáriz (Zuasti) (1773), los hermanos Juan Bautista Aguirre Uztáriz (Dona María) (1772) y Juan Ignacio Aguirre Uztáriz (Dona María) (1772).

${ }^{61}$ Miguel José Gastón de Iriarte Elizacoechea (Errazu) (1733), Francisco Dolarea Gastón de Iriarte (Gaztelu) (1775), Joaquín Gastón de Iriarte Cortejarena (Errazu) (1782).

62 Juan Echenique Micheo (Vera) (1781), Pedro Micheo Indacoechea (Saldías) (1798). Probablemente emparentados con los Uztáriz y los Dolarea-Gastón.

63 Pedro Borda Monreal (Elvetea) (1744), Pedro Fermín Mendinueta Garro (Elizondo) (1741). 
sus adelantamientos", o pidiendo remedio para corregir los males resultados: autorizando castigos o buscando otras soluciones. ${ }^{64}$

En otro lugar hemos visto cómo el teniente general Miguel José Gastón de Iriarte seguía atentamente e impulsaba la carrera de sus hijos en la marina. En este caso, Miguel José escribía desde Isla de León, en febrero de 1790, frustrado por las malas notas en conducta de su hijo menor, Antonio Gastón de Iriarte Navarrete, y resuelto a retirarlo del seminario: "quedo con el sentimiento que V. puede considerar de la mala conducta que la nota expresa de mi hijo, en cuya consecuencia pienso en retirarle cuanto antes, por si a mi vista se puede enmendarle, respecto que aún puede tener remedio en atención a sus pocos años (...)". Tras cinco años en Vergara, Antonio fue matriculado por su padre como guardiamarina en la Academia de Cádiz.

No faltan tampoco cartas de las madres, sobre todo en ausencia de la figura paterna por viudedad o alejamiento temporal, así como, muy ocasionalmente, cartas de tíos, algún abuelo preocupado por su "idolatrado nieto", u otros parientes que ejercían como tutores y curadores de los niños.

Mostrar las bases familiares y el apadrinamiento que estuvieron en el origen de las carreras militares no supone negar el mérito. Es cierto que toda "economía grupal" (al menos en las culturas mediterráneas) tiende a potenciar a los miembros del grupo por encima de los ajenos, aunque estos tengan objetivamente mayor mérito. Pero eran necesarios unos mínimos.

En general, la percepción que tenemos a través de la documentación privada revela una exigencia por parte de las familias y de las instituciones: una preocupación de los padres y parientes por los resultados de sus vástagos, un seguimiento de sus pasos, una satisfacción sincera por sus éxitos -que se publicitan dentro de la parentela- y el silencio o la frustración declarada cuando los resultados no eran satisfactorios. Esto se entiende; muchas cosas estaban en juego. Los sujetos brillantes eran la esperanza y orgullo de la familia y, en efecto, de su carrera dependía la economía de sus "interesados", en la medida en que muchos recursos materiales e inmateriales llegarían a los suyos por su mano. Los sujetos incapaces suponían, cuando menos, una pérdida de oportunidades para la familia. Esto no quiere decir que fueran abandonados a su suerte. La economía grupal podía reciclarlos y no perder todo lo invertido en ellos. Mientras acataran la obediencia debida y cumplieran con las lealtades familiares, la familia les rescataría y les colocaría donde pudieran resultar funcionalmente útiles a la economía del grupo. Lo vimos claramente al analizar las trayectorias de dos hermanos de muy diferente valía que la familia destinaba a la carrera militar y que dieron resultados contrarios, Luis Gonzaga y José Joaquín Gastón de Iriarte. ${ }^{65}$

\section{Las relaciones personales de los oficiales y la configuración de sus redes sociales}

Desde temprana edad, los parientes de estos jóvenes se encargaban de insertarlos convenientemente en sus redes de relaciones. Analizando la entrada en el cuerpo

Chaparro SÁInZ, op. cit. (nota 53), pp. 129-152.

65 Imízcoz BeunZA, J. M.: "El patrocinio familiar: Parentela, educación y promoción de las elites vasco-navarras en la monarquía borbónica", en Chacón JimÉnez, F y Hernández Franco, J. (eds.): Familias, poderosos y oligarquías: Seminario "Familia y élite de poder en el reino de Murcia. Siglos XV-XIX, Murcia, Universidad de Murcia, 2001, pp. 93-130. 
de artillería de Luis Gastón de Iriarte, un jovencito de quince años, futuro mariscal de campo, pudimos observar cómo sus parientes lo presentaron a sus jefes militares como miembro de su familia y protegido suyo. Primero, su tío segundo Juan Francisco de Lastiri, secretario de la Cámara de Castilla, lo hizo llevar a la corte para presentarlo personalmente al comandante general de la artillería, el conde Lacy, quien había favorecido su ingreso en la academia de Segovia. Luego, le dirigieron a dicha ciudad, donde le esperaban otros parientes bien situados allí (Fermín Lorenzo Irigoyen y Dutari, canónigo de la catedral, y Miguel de Buztinaga Lastiri, contador principal de la intendencia y provincia de Segovia), que lo integraron en su círculo de relaciones y lo presentaron formalmente ante los jefes de la academia. ${ }^{66}$

En instituciones como el Seminario de Vergara se establecían relaciones personales que servían para integrar a los jóvenes en los círculos de las élites, no necesariamente como resultado de cálculos rebuscados, sino como lo más natural del mundo, a través del simple conocimiento personal y del aprecio mutuo de personas que se encuentran en la misma burbuja social. En otro lugar observamos estas relaciones de aprecio a través de las cartas del conde de Peñaflorida a Pedro Jacinto de Álava, consiliario de la Bascongada en Álava: expresiones de afecto sobre algunos jóvenes que salían del Seminario, noticias de sus ascensos posteriores, cosas todas que indican un aprecio personal y un seguimiento de su carrera. Qué duda cabe que estas amistades influyentes reportaban a los jóvenes agraciados seguridad en sí mismos y protección en los inicios de su carrera. En contrapartida, la institución se ganaba el afecto de ex-alumnos destinados a ocupar posiciones influyentes al cabo del tiempo.

Porque la Bascongada y el Seminario de Vergara eran también una red de poder. Su amplia lista de socios amigos comprendía cargos muy influyentes y el Seminario tenía estrechas conexiones con la corte, el ejército y la marina. Los miembros de estas familias seguían abundantes carreras militares y sus redes tenían conexiones privilegiadas con el mando militar. En otro lugar pudimos observar, por ejemplo, las relaciones que mantenían los directores de la Bascongada y de Vergara con el comandante de la Real Academia de guardias marinas Miguel José Gastón de Iriarte. También, cómo buscaron inmediatamente conectar con el nuevo ministro de marina, Antonio Valdés, nada más conocer su nombramiento y constatar que no formaba parte de su red de relaciones. ${ }^{67}$

\subsection{Las amistades en la milicia}

Con la institucionalización de un cursus reglado, con academias y formas de selección y de educación que los futuros oficiales compartían desde niños, su universo socio-cultural fue, en gran mediada, su entorno profesional: un entorno trabado por las relaciones de jerarquía y los vínculos de amistad (y sin duda de competencia y enemistad) entre militares.

La carrera militar propició relaciones de amistad muy intensas. Muchos se encontraban desde niños en las mismas trayectorias y en ellas establecían sus prime-

\footnotetext{
${ }_{66}$ Imízcoz Beunza, J. M.: "El capital relacional: Relaciones privilegiadas y redes de influencia en el Estado español del siglo XVIII, en Imízcoz Beunza, J. M. y Oliveri Korta, O. (coords.): Economía doméstica y redes sociales en el Antiguo Régimen, Madrid, Sílex, 2010, pp. 227-282.

67 Imízcoz BeunZA, op.cit. (nota 57).
} 
ras amistades. Estas llegaban a alcanzar sentimientos de gran intensidad, a juzgar por el dolor que se desborda al evocar la pérdida del amigo guardiamarina fallecido:

mi amado compañero [...] desde el punto q[ue] me faltó, no me deja el dolor un rato de reposo, y si hallo algun alivio es en llorar su desgraciada muerte, para mi tanto o mas sensible que la de un herm[ano], pues el cariño entre los dos [... era sin limites $[\ldots] .{ }^{68}$

Más allá de los sentimientos, estas amistades tenían un gran significado, tanto por las afinidades y valores que se compartían como por la función política que podían cobrar en el futuro. Manuel Godoy recordaba con emoción sus amistades juveniles en las Guardias reales, tras su ingreso en 1784: aquellos " [...] compañeros [...] con quienes trabé sendos lazos de amistad, y de aquel linaje de amistad verdadera y generosa que se engendra en la edad juvenil", y evocaba "lo mucho que nos amábamos y [...] el fruto que saqué de ellos en el estudio [...], en nuestras lecturas meditadas y en las sustanciosas conferencias que ocupaban nuestras horas libres". ${ }^{69}$

Algunas amistades iniciadas desde los primeros estudios continuaban cuando los amigos seguían el mismo cursus. Muchos colegiales del Seminario de nobles de Vergara se encontraron a continuación en las academias militares de Cádiz o Segovia y renovaban sus lazos. Este fue el caso de dos condiscípulos de Vergara que se encontraron de nuevo en la Academia de Artillería, en 1789. La amistad entre ambos fue útil para Luis Gastón de Iriarte, ya que su amigo, un año más avanzado en los estudios, le ayudaba a preparar los exámenes de geometría, sacrificando "horas de recreo y diversión". 70

En otros trabajos hemos observado algunas manifestaciones y efectos de esta amistad a partir de la correspondencia privada de Pedro José Gastón de Iriarte, guardia real y teniente coronel retirado del servicio activo, a mediados del siglo XVIII. En las Guardias, Pedro José trabó amistad con otros jóvenes como Martín Álvarez de Sotomayor, José Bértiz, Nicolás Ponte, Victorio Navia o Manuel Amat. Las cartas que se escribían revelan la intensidad de los intercambios entre amigos y algunas características de estas amistades. Los amigos comparten sentimientos intensos, experiencias, opiniones, solidaridades: ayuda sostenida, apoyo en las dificultades, consejos, recomendaciones: una fuerte voluntad de ayudar a los amigos, que se materializaba en intercambios de favores y servicios. No todos, no siempre, no del mismo modo, pero sí tendencialmente.

A medida que los amigos ascendían en la jerarquía militar y ocupaban cargos político-militares, estas amistades devenían un elemento importante de las redes de poder de los cuadros de la monarquía. La utilidad política de estas amistades ha sido puesta de relieve en diferentes trabajos. ${ }^{71}$ La correspondencia privada revela hasta qué punto fueron útiles para hacer carrera, alcanzar favores y ganar influencia.

68 ACGI, carta de Juan José de Elizalde y Uztáriz a Miguel José Gastón de Iriarte y Elizacoechea, Cádiz, 4 de octubre de 1783, comunicando el fallecimiento de su amigo Francisco Esteban Dolarea y Gastón de Iriarte, muerto en alta mar el 11 de julio de 1783 .

69 Godoy, M.: Memorias, edición de E. La Parra y E. Larriba, Alicante, Universidad de Alicante, 2008, p. 125.

70 ACGI, carta de Juan Javier Gastón de Iriarte a Pedro José Gastón de Iriarte. Toledo, 26 de abril de 1789

71 La Parra, E.: Manuel Godoy. La aventura del poder, Barcelona, Tusquets, 2002; AndúJAr CaStillo, F., "Nepotismo, clientelismo y fidelidad. De Floridablanca a Godoy", en Cuaderno de Historia Moderna. Anejo VII (2008), pp. 179-211. 
La utilidad de las amistades militares fue particularmente relevante en el caso de las Guardias Reales, dada su importancia para la producción de generales y cuadros político-militares de la monarquía. De los amigos de Pedro José Gastón en las Guardias, por ejemplo, Martín Álvarez de Sotomayor, conde de Colomera, fue virrey de Navarra, consejero del Consejo de Estado y del Consejo de Guerra, capitán general de Castilla la Nueva, Inspector General de la Artillería de España e Indias y Comandante general del cuerpo de Artillería, Gentilhombre de Cámara del rey y Grande de España. José Bértiz Salcedo fue virrey del Río de la Plata e Inspector general de las Milicias del reino. Nicolás Llano Ponte, teniente general. Manuel Amat, virrey del Perú y Gentilhombre de la Real Cámara. Victorio Navia, capitán general del reino de Valencia, de Castilla la Nueva, y Gentilhombre de la Real Cámara. ${ }^{72}$

Los amigos se ofrecían a disposición de sus amigos, ponían a su favor la influencia personal que les daba su elevación en los cargos. También les ofrecían la influencia de las relaciones útiles que iban estableciendo al filo de su carrera. Un excelente ejemplo es la forma en que Martín Álvarez de Sotomayor ponía al servicio de Pedro José Gastón a su amigo José Portugués, entonces oficial primero de la Secretaría de Guerra: "El amigo Portugués lo tendrá vuestra merced pronto a esforzar su pretensión, y puedo hoy con su influjo bastante". ${ }^{73}$

Más allá de los aspectos personales y de la configuración de redes de poder, estos encuentros y amistades tuvieron consecuencias de mayor calado, aunque menos visibles. El ejército borbónico funcionó como un intenso crisol. En él, jóvenes provenientes de todos los orígenes geográficos y de diversos sectores de las élites - de la aristocracia y la nobleza señorial a los campesinos hidalgos elevados a través del comercio- se encontraban en las mismas carreras, se igualaban al servicio del rey, compartían experiencias semejantes y se hacían amigos. Incluso, en esta nueva matriz, los individuos parecen despojarse de sus atributos de origen y linaje para llamarse entre sí por su primer apellido, sin títulos estamentales: Álvarez, Gastón, Amat, Ponte, Navia, Bértiz. Como se llaman a sí mismos en sus cartas: "el amigo Álvarez", "el amigo Ponte", "el amigo Navia", "el amigo Portugués". En medio del entramado social del antiguo régimen, que seguía siendo profunda y mayoritariamente un agregado de estados, comunidades territoriales y corporaciones diferentes, esta mezcla de orígenes y de estatutos al servicio del rey fue, sin duda, una matriz muy eficaz para configurar, social y culturalmente, una parte muy significativa de las "redes sociales y políticas que podrían ser consideradas como los inicios de la nación española". ${ }^{74}$ Es nuestra hipótesis de trabajo.

\subsection{Las relaciones de las élites militares en los círculos cortesanos...}

Hasta ahora hemos visto cómo, en la carrera militar, se fueron configurando unos entornos profesionales específicos que, al filo de unas vías regladas de carrera y de endogamias de diversos tipos, contribuyeron a crear estrechos vínculos entre militares, especialmente de amistad y de camaradería. Sin embargo, al mismo tiempo, estos oficiales formaban parte de redes sociales mucho más amplias que desbordaban la institución. En particular, estaban conectados, a través de relaciones de parentesco

Base de datos Fichoz, no 000051, 003013, 003216, 000053 y 000568.

ACGI, carta de Martín Álvarez de Sotomayor a Pedro José Gastón de Iriarte. Madrid, 25 de febrero de (¿1758?).

Ringrose, D. R.: España, 1700-1900: el mito del fracaso, Madrid, Alianza, 1996, p. 83. 
y de amistad, con hombres de otros sectores profesionales de la administración real, de la economía política y de los intelectuales vinculados al reformismo borbónico.

En otro trabajo hemos mostrado este entorno a partir del testimonio de un joven guipuzcoano, José María de Zuaznávar y Francia, que llegó a la corte en 1784, con 19 años, y salió de ella ocho años después, en 1792, para embarcar en Cádiz rumbo a las islas Canarias, al ser nombrado Fiscal de aquella Audiencia. ${ }^{75}$ Los encuentros de este joven en la corte y luego en el camino a Cádiz ofrecen un ejemplo excelente de las redes sociales de estas élites cortesanas y militares que venimos observando.

La propia familia Zuaznávar tenía una composición plural. De los cuatro varones Zuaznávar y Francia, dos siguieron carreras militares -Pablo en la Artillería y José Joaquín en la marina- uno, Javier María, en el alto clero, y nuestro José María en la magistratura. En la corte, José María se inserta en el círculo de relaciones tejidas por sus parientes en la generación anterior, en que se mezclan militares, administradores y financieros de la corona.

Por un lado, se encuentra con una serie de parientes militares, con apellidos Zuaznávar, Jáuregui, Aróstegui, Iturrigaray que, como hemos visto, eran descendientes de familias de comerciantes, dirigentes de la compañía de tabaco de la Habana, durante el reinado de Felipe $\mathrm{V}^{76}$, que, posteriormente, habían ascendido al generalato y al gobierno de virreinatos en Indias. Así mismo, el círculo de parentesco de Zuaznávar en la corte se extendía a personajes bien establecidos en el Consejo de Hacienda, la dirección de Correos, la secretaría de Estado y el alto clero.

El joven José María Zuaznávar se insertó más especialmente en el círculo de relaciones del marqués de Iranda, Simón de Aragorri, uno de los círculos más concurridos de la corte en aquel momento. En su tertulia entró en contacto con ministros y cónsules extranjeros, oficiales de las Secretarías del Despacho, literatos, consejeros, generales, etc. que acudían allí habitualmente. Entre otros, intimó con Bernardo de Iriarte, Manuel de Lardizábal y Uribe, don Miguel de Gálvez, consejero de Guerra, el general don Antonio Ricardos, el marqués de Bajamar, o el cardenal Lorenzana, arzobispo de Toledo.

La parentela del marqués de Iranda comprendía un importante contingente de militares de alta graduación. Su mujer, doña Josefa de la Torre, era prima del teniente general marqués de Torremanzanal, futuro Secretario del Despacho de Guerra. En esta parentela se hallaban entroncadas familias como los Aragorri, Las Casas, O'Reilly, con ramificaciones La Cuadra, Mollinedo, Urrutia, etc., que dieron a lo largo del siglo abundantes carreras en el ejército y en los más altos cargos de la monarquía (ver diagrama $\mathrm{n}^{\circ} 5$ ). Los O'Reilly formaban parte de las familias de origen irlandés que destacaron especialmente en carreras militares. ${ }^{77}$

José María Zuaznavar se relacionó en este círculo de parientes y amigos de los Aragorri y estableció amistad con importantes militares, entre los que destacaban Luis de las Casas y Aragorri, sobrino del marqués de Iranda, teniente general de los reales ejércitos y comandante general de la Isla de Cuba, el conde O'Reilly, capitán

75 Zuaznavar y Francia, J. M.: Memorias para la vida de don José María de Zuaznavar y Francia, individuo de las Reales Academias Española, de la Historia, y de la Grecolatina, por el mismo Zuaznavar, San Sebastián, Imprenta de Ignacio Ramón Baroja, 1834.

76 Imízcoz Beunza y Guerrero EleCAlde, op. cit. (nota 28).

77 Andújar Castillo, F.: "Familias irlandesas en el Ejército y en la Corte borbónica", en García HernáN, E. y Recio Morales, O. (coords.): Extranjeros en el Ejército. Militares irlandeses en la sociedad española, 15801818, Madrid, Ministerio de Defensa, 2007, pp. 271-295. 
general de Andalucía e Inspector general de la Infantería de España e Indias, casado con doña Rosa de Las Casas y Aragorri, natural de San Sebastián, su hermano el teniente general don Domingo de O'Reilly, gentil hombre de cámara al servicio del infante don Antonio, el teniente coronel don Gonzalo O'Farril, futuro teniente general y ministro de Guerra josefista.

Las visitas y los encuentros que hace José María en el camino de Madrid a Cádiz, en 1792, revelan la extensión de las redes de estas familias y su presencia destacada en diversos centros de poder, en particular la importancia de sus amistades en el ejército y la marina. Entre otros, se encuentra con su amigo el teniente general Luis Urbina y con su amigo Javier Castaños Aragorri, futuro capitán general y duque de Bailén, que viajaba en compañía de su sobrino, Alejandro O'Reilly, hijo del teniente general conde O'Reilly. Visita al teniente general de marina Gabriel Aristizabal, íntimo amigo de su padre, y al teniente general José Mazarredo, amigo íntimo de su padre y suyo propio.

En definitiva, el ejemplo de Zuaznávar muestra el entorno social y cultural del que formaban parte los altos grados militares de unas parentelas que se hallaban especialmente elevadas en el gobierno de la monarquía. Revela cómo, más allá de sus amistades y relaciones militares, estos oficiales se hallaban muy conectados por vínculos de parentesco, de amistad y de sociabilidad con otros sectores de la alta administración, de la economía del Estado y de la cultura, tanto en los círculos de la corte como en los centros de la monarquía y del imperio en que gobernaron al servicio del rey.

\section{3. ...y en los sectores reformistas ilustrados}

Hace algunos años, observando el perfil social de los dirigentes de la Real Sociedad Bascongada de los Amigos del País, nos llamó la atención la importancia de las carreras militares y administrativas en el seno de estas familias, algo que la historiografía tradicional no había destacado. ${ }^{78}$ Los veinticuatro socios de número de la Bascongada formaban parte de un amplio grupo de familias de las provincias vascas que estaban emparentadas entre sí en diversos grados ${ }^{79}$ y que se hallaban especialmente vinculadas a las carreras de la corte, la alta administración, el ejército y el imperio colonial desde el reinado de Felipe V. Su tronco se había formado en torno al grupo cortesano de Juan de Idiáquez y Eguía, a quien hemos visto en la fundación y mando de las Guardias de Infantería Española, de su primo Aréizaga Corral, y de los Aguirre Salcedo, marqueses de Montehermoso. Otras familias se habían ido agregando a través de matrimonios. Algunas de ellas, procedentes de ascensos recientes en el comercio y las Indias, como los Munibe, Gortázar, Mazarredo, Gómez de la Torre, Urbina, habían elevado a sus hijos en carreras militares y administrativas al servicio del rey.

De este modo, encontramos una abundante la nómina de militares en las familias Idiáquez, Aréizaga, Álava Sáenz de Navarrete y Álava Esquivel, Aguirre Ayanz, Ortés de Velasco, Lili e Idiáquez y Lili Moyua, Barreneche Castaños, Corral Agui-

78 Imízcoz Beunza y Chaparro Sáinz, op. cit. (nota 18), pp. 993-1027.

79 Aguinagalde Olaizola, B.: “¿Por qué los archivos de la Bascongada son complicados? Notas archivísticas a un Coloquio sobre la Amistad", en Risco, A. y UrkiA, J. M. (dir.): Amistades y Sociedades en el siglo XVIII, San Sebastián, Toulouse, RSBAP, Université de Toulouse-le Mirail, 2001, pp. 21-41 
rre, Esquivel Peralta, Mata Linares Vázquez, Ibarra Urdanegui, Mazarredo Gortazar, Mazarredo Gómez de la Torre, Moyua Ozaeta, Urbina Ortiz de Zárate, Salazar Salazar, o Sánchez Samaniego Zavala. En otros lugares hemos detallado todas sus carreras.

A lo largo del siglo, la política de estas familias había consistido en guardar un heredero al frente del mayorazgo y sacar al resto de hermanos fuera del país, a carreras militares, administrativas y eclesiásticas más o menos elevadas al servicio del rey. La historiografia ha percibido tradicionalmente al patricio provincial que se quedaba en casa, pero no tanto a la amplia parentela que seguía carreras al servicio de la corona y negocios en todos los territorios de la monarquía. Esta desconexión ha sido la tónica habitual y ha producido una historiografía compartimentada, sin perspectiva de red social.

La presencia de militares en el total de 1630 socios inscritos en la Bascongada entre 1765 y 1793 fue igualmente destacada. De los 591 miembros cuya ocupación identificamos, 251 , el $42 \%$, eran militares, de los cuales 198 en el ejército y 53 en la armada. ${ }^{80}$ En muchos casos se trataba de hijos de familias que seguían el mismo patrón que hemos observado, guardar un heredero en el país y sacar a los hijos que se pudiera a medrar en las carreras y negocios de la monarquía, donde los encontramos en todo el orbe del imperio.

Algo semejante encontramos, aunque en una proporción muy inferior, en los fundadores y socios de la Real Sociedad Tudelana de los Deseosos del Bien Público, con familias como los Magallón-Mencos-Armendáriz, González de Castejón o Cortés que contaban a varios de sus miembros en la milicia. ${ }^{81}$

Todo esto conecta con una abundante historiografía que ha visto en determinados sectores del ejército borbónico una fuente de modernidad, por el carácter científico y reformista de muchas de sus prácticas. Formados en los colegios de nobles, en las academias militares o en los regimientos de las Guardias Reales, que se encontraban entre las principales canteras de cuadros políticos de los Borbones, los futuros oficiales recibían una educación específica, con perfiles técnicos, incluso científicos, en las "armas sabias", y una cultura política regalista. Es lógico suponer que, en estas trayectorias y experiencias compartidas, sus mentes se formaron en valores semejantes.

Entre otros autores, Gloria Franco ha enfatizado cómo nos hallamos ante militares con un alto grado de formación, especialización y profesionalización ${ }^{82}$, y ha mostrado la implicación de militares, concretamente de los oficiales de las secretarías del despacho de Guerra y Marina, en la creación, dirección y actividades de las academias reales, de las sociedades económicas y de las principales tertulias políticas, en la segunda mitad de la centuria. ${ }^{83}$ Algunos militares estuvieron más especialmente

80 Martínez Ruiz, J.: Catálogo general de individuos de la R.S.B. de los Amigos del País (1765-1793), San Sebastián, RSBAP, 1985, pp.19-122.

81 Guijarro Salvador, P.: “Los Deseosos del Bien Público": Protagonistas, mentalidades y proyectos en Tudela durante la Ilustración (1750-1808), tesis doctoral, Pamplona, Universidad de Navarra, 2009, pp. 313-314 y árbol genealógico n. ${ }^{\circ} 6$.

82 Franco Rubio, op. cit. (nota 17), p. 167.

83 Franco Rubio, G. A.: "Militares ilustrados y prácticas de sociabilidad", en Revista de Historia Moderna. Anales de la Universidad de Alicante, 22 (2004), pp. 369-402; Franco Rubio, G. A.: "El ejercicio del poder en la España del siglo XVIII. Entre las prácticas culturales y las prácticas políticas”, en LóPEZ-CoRDón, M. V. y Luis, J.-P. (coords.): "La naissance de la politique moderne en Espagne", Mélanges de la Casa de Velázquez, 35-1 (2005), pp. 51-77; Sánchez Blanco, F.: El Absolutismo y las Luces en el reinado de Carlos III, Madrid, Marcial Pons, 2002, pp. 121-149. 
vinculados a las políticas reformistas de los Borbones. Estudiaron, escribieron, propusieron reformas, participaron en el debate de ideas, se dirigieron a la opinión pública a través de la prensa, difundieron los ideales de la ilustración europea. ${ }^{84}$ Desde luego, no todos tuvieron el mismo carácter ilustrado. También, todo es relativo $\mathrm{y}$, a la hora de hablar de modernidad, de reformismo o de ilustración, hay que comparar lo que es comparable. En este caso, la referencia debe ser el estado de la mayoría de la aristocracia española y la enseñanza escolástica y jurisdiccional en que se había formado tradicionalmente las élites políticas españolas.

En el fondo, lo que nos parece especialmente significativo, más allá del perfil cultural de algunos militares, de su carácter más o menos ilustrado, de sus prácticas literarias y de sus opiniones, es el papel que jugaron los oficiales del ejército borbónico como agentes de la política reformista en la segunda mitad de la centuria y, con ello, en la construcción del primer estado español.

84 Sánchez Blanco, F.: La Ilustración goyesca. La cultura en España durante el reinado de Carlos IV (17881808), Madrid, CSIC, 2007, pp.110-138; García Hurtado, M. R.: El arma de la palabra. Los militares españoles y la cultura escrita en el siglo XVIII (1700-1808), A Coruña, Universidade da Coruña, 2002. 


\section{Anexo 1}

Oficiales vascos y navarros en el ejército, a partir del grado de coronel (siglo XVIII)

\begin{tabular}{|c|c|c|c|c|c|}
\hline NOMBRE & LUGAR & NAC. & GRADO & ARMA & FECHA \\
\hline ABARCA AZNAR, Silvestre & Lumbier & 1707 & Teniente general & $\begin{array}{l}\text { Infant./ } \\
\text { ingeniero }\end{array}$ & 1776 \\
\hline ABURRUZA ELCORO, José Ramos & Vergara & 1777 & Coronel & Infantería & $1816<$ \\
\hline ACUÑA IRIGOYEN, Ramón & Pasajes & 1768 & Brigadier & Caballería & 1799 \\
\hline AGUIRRE LANDÁZURI, Manuel Mariano & Munguía & 1745 & Mariscal de campo & Caballería & 1795 \\
\hline $\begin{array}{l}\text { AGUIRRE ORENDAIN, Francisco Javier (II } \\
\text { marqués de la Paz) }\end{array}$ & Oñate & 1716 & Coronel & Caballería & 1745 \\
\hline AGUIRRE ZUAZO, José María & Vitoria & 1733 & Teniente general & Caballería & 1783 \\
\hline ÁLAVA ARANGUREN, Gaspar Melchor & Vitoria & 1705 & Maestre de campo & & $1754<$ \\
\hline ÁLAVA ESQUIVEL, Miguel Ricardo & Vitoria & 1772 & Teniente general & Infantería & 1814 \\
\hline $\begin{array}{l}\text { ÁLAVA SAENZ DE NAVARRETE, José } \\
\text { Manuel }\end{array}$ & Vitoria & 1743 & $\begin{array}{l}\text { Coronel de dragones } \\
\text { provinciales de Puebla de } \\
\text { los Ángeles }\end{array}$ & Infantería & 1796 \\
\hline $\begin{array}{l}\text { ÁLAVA SAENZ DE NAVARRETE, Luis } \\
\text { Gonzaga }\end{array}$ & Vitoria & 1753 & Brigadier & Infantería & 1809 \\
\hline ÁLAVA, Francisco & Vitoria & 1683 & Mariscal de campo & Infantería & 1745 \\
\hline ANDONAEGUI, José & Marquina & 1685 & Teniente general & Infantería & 1754 \\
\hline ANSOATEGUI BARRON, Rafael & Pasajes & 1745 & Brigadier & Infantería & 1815 \\
\hline $\begin{array}{l}\text { ARAMBURU ATORRASAGASTI, José } \\
\text { Basilio }\end{array}$ & Tolosa & 1683 & Teniente general & Infantería & 1740 \\
\hline ARANDA AMÉZAGA, Joaquín & Anuncibay & 1694 & Mariscal de campo & Caballería & 1741 \\
\hline ARANDA SALCEDO, Ignacio & $\begin{array}{l}\text { Orcio de } \\
\text { Vizcaya }\end{array}$ & 1684 & Coronel & Caballería & $1710<$ \\
\hline ARANDA, Cristobal ¿??? & Orozco & 1690 & $\begin{array}{l}\text { Exempto de la compañía } \\
\text { española de la Guardia de } \\
\text { corps }\end{array}$ & & $1736<$ \\
\hline ARANGUREN, Manuel María & Mondragón & 1794 & Coronel & Infantería & $1820<$ \\
\hline $\begin{array}{l}\text { AREIZAGA ALDUNCÍN, Juan Carlos (barón } \\
\text { de Areizaga) }\end{array}$ & $\begin{array}{l}\text { Villarreal } \\
\text { (Urrechu) }\end{array}$ & $1750>$ & Teniente general & Caballería & $1808<$ \\
\hline AREIZAGA CORRAL, Carlos & Villarreal & 1680 & Capitán general & Infantería & 1754 \\
\hline AREIZAGA IRUSTA, Juan Carlos & $\begin{array}{l}\text { Villarreal } \\
\text { (Alava) }\end{array}$ & 1720 & Coronel & Infantería & 1750 \\
\hline $\begin{array}{l}\text { ARGAIN YOLDI, Pedro (I marqués de la Real } \\
\text { Corona) }\end{array}$ & $\begin{array}{l}\text { Maya de } \\
\text { Baztán }\end{array}$ & 1685 & Teniente general & Infantería & 1747 \\
\hline $\begin{array}{l}\text { ARIZCUN BEAUMONT, José Francisco } \\
\text { (barón de Beorlegui) }\end{array}$ & Pamplona & 1728 & Coronel & Infantería & $1797<$ \\
\hline
\end{tabular}




\begin{tabular}{|c|c|c|c|c|c|}
\hline ARIZCUN BORDA, Francisco Manuel & Elizondo & 1738 & Brigadier & Infantería & 1789 \\
\hline ARMENDÁRIZ ÁLVAREZ EULATE, Bernabé & Sangüesa & 1695 & Mariscal de campo & & 1754 \\
\hline $\begin{array}{l}\text { ARMENDÁRIZ PERURENA, José (I m. de } \\
\text { Castelfuerte) }\end{array}$ & Pamplona & 1670 & Capitán general & Infantería & 1728 \\
\hline $\begin{array}{l}\text { ARMENDÁRIZ, Juan Esteban (III marqués de } \\
\text { Castelfuerte) }\end{array}$ & Pamplona & 1716 & Coronel & Caballería & 1767 \\
\hline $\begin{array}{l}\text { ARMENDÁRIZ PERURENA, Juan Francisco } \\
\text { (II m Castelfuerte) }\end{array}$ & Pamplona & 1675 & Teniente general & Caballería & 1734 \\
\hline $\begin{array}{l}\text { ARMONA MURGA, Matías (II marqués del } \\
\text { Real Agrado) }\end{array}$ & Respaldiza & 1731 & Brigadier & Infantería & 1791 \\
\hline AROSTEGUI LARREA, Martín Esteban & Aranaz & 1721 & Brigadier & Caballería & 1763 \\
\hline ARTEAGA IDIAQUEZ, José & Lazcano & 1751 & Teniente general & Infantería & 1798 \\
\hline ARTEAGA LAZCANO, Luis & $\begin{array}{l}\text { Villafranca } \\
\text { de Oria }\end{array}$ & $1725<$ & Teniente general & Infantería & 1760 \\
\hline BARRAICOA, Diego & Bilbao & 1698 & Brigadier & Infantería & $1754<$ \\
\hline BEDIA CUADRA, Enrique & Valmaseda & $1723<$ & Brigadier & Infantería & 1779 \\
\hline BERTODANO, Alberto & Tudela & 1660 & Brigadier & & 1719 \\
\hline BRETÓN, Eugenio & Aldeanueva & 1710 & Teniente general & & 1779 \\
\hline BUZUNARIZ LATERRA, Tomás & Artajona & 1747 & Mariscal de campo & $\begin{array}{l}\text { Infant./ } \\
\text { ingeniero }\end{array}$ & $1814<$ \\
\hline $\begin{array}{l}\text { CABALLERO VICENTE CAMPO, Jerónimo } \\
\text { (I m. de Caballero) }\end{array}$ & $\begin{array}{l}\text { Aldeavilla de } \\
\text { Ribera }\end{array}$ & 1721 & Teniente general & Caballería & 1789 \\
\hline $\begin{array}{l}\text { CAGIGAL VEGA, Fernando (IV marqués de } \\
\text { Casa-Cagigal) }\end{array}$ & $\begin{array}{l}\text { San } \\
\text { Sebastián }\end{array}$ & 1753 & Teniente general & Caballería & 1814 \\
\hline CASAS ARAGORRI. Luis & Vizcaya & 1745 & Teniente general & Infantería & 1791 \\
\hline $\begin{array}{l}\text { CASTILLO FAJARDO, Juan Bautista (Grande } \\
\text { de España) }\end{array}$ & $\begin{array}{l}\text { San } \\
\text { Sebastián }\end{array}$ & 1696 & Capitán general & Caballería & 1770 \\
\hline CLAVERÍA, Antonio & $\begin{array}{l}\text { San } \\
\text { Sebastián }\end{array}$ & 1760 & Coronel & Artillería & $1805<$ \\
\hline CORRAL AGUIRRE, Carlos & Vitoria & 1741 & Brigadier & Infantería & 1789 \\
\hline CORTES CAPARROSO, José & Tafalla & 1664 & Brigadier & Caballería & 1719 \\
\hline DAOIZ GUENDICA, Berenguer & Pamplona & 1745 & Coronel & & $1788<$ \\
\hline $\begin{array}{l}\text { DIAZ PIMIENTA ZALDIVAR, Francisco } \\
\text { Antonio }\end{array}$ & Orduña & 1662 & Mariscal de campo & Caballería & 1705 \\
\hline DURAN BALAZAGA, José Joaquín & Cascante & 1760 & Mariscal de campo & Infantería & $1812<$ \\
\hline DUSMET LADRON, Nicolás & Fuenterrabía & 1783 & Coronel & Infantería & $1817<$ \\
\hline ECHALAZ, Lorenzo & Echalar & 1721 & Brigadier & Infantería & 1783 \\
\hline ECHENIQUE ECHENIQUE, Pedro Gregorio & Arizcun & 1715 & $\begin{array}{l}\text { Coronel de milicias } \\
\text { Santiago de Chile }\end{array}$ & Caballería & 1787 \\
\hline ECHEVERRIA HURTADO MENDOZA, Pedro & Sestao & 1756 & Teniente general & Infantería & 1815 \\
\hline EGUIA LOPEZ LETONA, Francisco Ramón & Bilbao & 1750 & Capitán general & Infantería & 1823 \\
\hline
\end{tabular}




\begin{tabular}{|c|c|c|c|c|c|}
\hline EGUIA SAEZ BURUAGA, Nazario & Durango & 1777 & Teniente general & Infantería & 1829 \\
\hline EGUIARRETA ULLOA, Bernardo & Pamplona & $1700<$ & Brigadier & Infantería & 1754 \\
\hline ELIO OLONDRIZ, Francisco Javier & Pamplona & 1764 & Brigadier & Infantería & 1808 \\
\hline EMPARAN AZCUE, Francisco & Azpeitia & 1676 & Teniente general & & 1734 \\
\hline EMPARAN ORBE, Miguel José & Azpeitia & 1756 & Mariscal de campo & Caballería & 1815 \\
\hline EMPARAN ORBE, Vicente & Azpeitia & 1747 & Mariscal de campo & & $1810<$ \\
\hline ESLAVA CAVERO, José Antonio & $\begin{array}{l}\text { Ibarra /Quito } \\
\text { Perú?? }\end{array}$ & 1735 & Teniente general & Infantería & 1793 \\
\hline ESLAVA LASAGA, Sebastián & Enériz & 1685 & Capitán general & Infantería & 1741 \\
\hline $\begin{array}{l}\text { ESLAVA MONZÓN, Gaspar (I marqués de la } \\
\text { Real Defensa) }\end{array}$ & Enériz & 1713 & Coronel & Infantería & $1760<$ \\
\hline ESPOZ MINA, Francisco & Idocin & 1781 & Teniente general & Infantería & 1822 \\
\hline FONSDEVIELA ONDEANO, José & $\begin{array}{l}\text { San } \\
\text { Sebastián }\end{array}$ & 1729 & Brigadier & Infantería & 1783 \\
\hline GACITUA, Francisco & Bilbao & 1750 & Mariscal de campo & Artillería & 1810 \\
\hline GANTE, Basilio & Navarra & 1680 & Mariscal de campo & Infantería & 1743 \\
\hline GARCIA ARISTIA LOIGORRI, Martín & Corella & 1759 & Teniente general & Artillería & 1815 \\
\hline GARCIA OLLOQUI, Francisco Antonio & $\begin{array}{l}\text { Villafranca d } \\
\text { Navarra }\end{array}$ & 1720 & Brigadier & Infantería & 1783 \\
\hline GASTÓN CORTEJARENA, Luis & Errazu & 1774 & Mariscal de campo & Artillería & 1835 \\
\hline GIL GAINZA ECHAGUE, Martín & Enériz & $1660<$ & Coronel & $\begin{array}{l}\text { Infant./ } \\
\text { ingeniero }\end{array}$ & $1735<$ \\
\hline $\begin{array}{l}\text { GIRON LAS CASAS, Pedro Agustín (I duque } \\
\text { de Ahumada) }\end{array}$ & Pasajes & 1778 & Teniente general & & 1814 \\
\hline GOICOECHEA URRUTIA, Gaspar & Elorrio & 1777 & Brigadier & Ingeniero & 1813 \\
\hline GOMEZ TORRE JARABEITIA, José Nicolás & Bilbao & 1706 & Mariscal de campo & Infantería & 1779 \\
\hline $\begin{array}{l}\text { GONZÁLEZ BASSECOURT, Francisco } \\
\text { Fernando }\end{array}$ & Pamplona & 1725 & Teniente general & Infantería & 1776 \\
\hline GONZÁLEZ BASSECOURT, Miguel & Pamplona & 1719 & $\begin{array}{l}\text { Coronel agregado ejército } \\
\text { Lombardía }\end{array}$ & Infantería & $1759<$ \\
\hline GONZÁLEZ CASTEJÓN VERAIZ, Francisco & Tudela & 1777 & Mariscal de campo & & 1809 \\
\hline $\begin{array}{l}\text { GONZÁLEZ SEPÚLVEDA ECHALAZ, } \\
\text { Lorenzo }\end{array}$ & Echalar & 1721 & Coronel & Infantería & $1775<$ \\
\hline GOYENECHE MARTIARENA, Justo Pastor & Elizondo & 1709 & Coronel & Caballería & $1775<$ \\
\hline GUENDICA MENDIETA, José Joaquín & $\begin{array}{l}\text { San } \\
\text { Sebastián }\end{array}$ & 1722 & Coronel & Infantería & $1776<$ \\
\hline GUENDICA MENDIETA, Luis & Bilbao & 1684 & Teniente general & Infantería & 1744 \\
\hline GUENDICA, Francisco & Pamplona & 1724 & Mariscal de campo & Infantería & 1789 \\
\hline HUART PICASARY, Gabriel Manuel & Navarra & $1712<$ & Mariscal de campo & Infantería & 1754 \\
\hline $\begin{array}{l}\text { HURTADO AMEZAGA, Baltasar (I marqués } \\
\text { Riscal de Alegre) }\end{array}$ & Bilbao & 1657 & Teniente general & & 1709 \\
\hline
\end{tabular}




\begin{tabular}{|c|c|c|c|c|c|}
\hline HURTADO AMEZAGA, Juan Antonio & Bilbao & 1664 & Teniente general & Caballería & 1706 \\
\hline HURTADO MENDOZA, José & Bilbao & 1670 & Mariscal de campo & Caballería & 1710 \\
\hline IBARRA URDANEGUI, Luis Augustín & Bilbao & 1716 & Coronel & Caballería & $1773<$ \\
\hline $\begin{array}{l}\text { IDIAQUEZ EGUIA, Juan (I duque Granada } \\
\text { de Ega) }\end{array}$ & Azcoitia & 1665 & Capitán general & & $1729<$ \\
\hline IDIAQUEZ EGUIA, Tomás & Azcoitia & $1675<$ & Teniente general & & 1719 \\
\hline IDIAQUEZ GARRO, Antonio & Pamplona & 1716 & Brigadier & Infantería & 1754 \\
\hline IDIAQUEZ PALAFOX, Francisco Borja & Estella & 1755 & Teniente general & & 1793 \\
\hline IMAZ ALTOLAGUIRRE, José & Ataun & 1761 & Mariscal de campo & Infantería & 1815 \\
\hline IRUEGAS ALDAMA, Mateo & Salmanton & 1758 & Coronel & & 1802 \\
\hline ITURRALDE ASCÓ, Juan Domingo & Lecaroz & 1759 & Coronel & & 1815 \\
\hline JARABEITIA GUENDICA, José Bernardo & Bilbao & 1720 & Brigadier & Infantería & 1783 \\
\hline JAUREGUI AROSTEGUI, Manuel Francisco & Pamplona & 1767 & Brigadier & Infantería & 1808 \\
\hline JAUREGUI ALDECOA, Agustín & Lecaroz & 1711 & Teniente general & & 1779 \\
\hline JAUREGUIONDO, Julián Francisco & $\begin{array}{l}\text { San } \\
\text { Sebastián }\end{array}$ & 1701 & Brigadier & Infantería & 1754 \\
\hline LADRÓN CEGAMA, Santos & Lumbier & 1784 & Brigadier & & 1823 \\
\hline LARDIZABAL, José Javier & Tolosa & 1777 & Teniente general & Infantería & 1814 \\
\hline LARRECHEA ECHEGARAY, Francisco & Lecaroz & 1728 & Mariscal de campo & & 1794 \\
\hline LILI MOYUA, Miguel (conde de Alacha) & Cestona & $1756 \mathrm{c}$ & Brigadier & Infantería & 1809 \\
\hline LONGA ANCHIA, Francisco Tomás & Mallavia & 1783 & Teniente general & Infantería & 1825 \\
\hline MANRIQUE ARANA, Juan Francisco & Vitoria & 1655 & Capitán general & & 1710 \\
\hline MAZARREDO GOMEZ TORRE, Francisco & Bilbao & 1772 & Brigadier & Infantería & 1810 \\
\hline $\begin{array}{l}\text { MENCOS AYANZ, Rafael (Conde de } \\
\text { Guendulain) }\end{array}$ & Tafalla & 1705 & Coronel & Infantería & 1759 \\
\hline MENCOS ESLAVA, José María & Pamplona & 1773 & Mariscal de campo & Infantería & $1833<$ \\
\hline MENDINUETA MÚZQUIZ, Pedro & Elizondo & 1736 & Capitán general & Infantería & 1816 \\
\hline MENDINUETA GARRO, Pedro Fermín & Elizondo & 1725 & Mariscal de campo & Infantería & 1802 \\
\hline MENDIZABAL IRAETA, Gabriel & Vergara & 1764 & Teniente general & Infantería & 1810 \\
\hline MENDOZA HERMIAGA, Joaquín & Pamplona & 1733 & Mariscal de campo & & 1802 \\
\hline MICHELENA MENDINUETA, Juan Luis & $\begin{array}{l}\text { San } \\
\text { Sebastián }\end{array}$ & 1782 & Mariscal de campo & Infantería & 1825 \\
\hline MIÑANO DAOIZ, José Luis & Tudela & 1742 & Mariscal de campo & & 1806 \\
\hline MONTERO SOPELANA, Manuel & Bilbao & 1696 & Teniente general & Infantería & 1761 \\
\hline MONZÓN LOPEZ ESLAVA, Fermín & Artajona & 1735 & Coronel & Infantería & $1783<$ \\
\hline MUNARRIZ IRAIZOZ, Juan Manuel & Estella & 1761 & Mariscal de campo & Artillería & 1820 \\
\hline MUÑOZ SAN CLEMENTE, Francisco & Pamplona & 1755 & Brigadier & Caballería & 1802 \\
\hline O'DONNELL ANETHAN, Enrique José & $\begin{array}{l}\text { San } \\
\text { Sebastián }\end{array}$ & 1776 & Teniente general & Infantería & 1810 \\
\hline OROVIO AROSTEGUI, Joaquín & $\begin{array}{l}\text { San } \\
\text { Sebastián }\end{array}$ & 1737 & Coronel & Infantería & 1789 \\
\hline
\end{tabular}




\begin{tabular}{|c|c|c|c|c|c|}
\hline $\begin{array}{l}\text { OZTA MUZQUIZ, Juan Casimiro (marqués de } \\
\text { Rivascacho) }\end{array}$ & Elvetea & $1745<$ & $\begin{array}{l}\text { Coronel milicias infantería } \\
\text { Méjico }\end{array}$ & Infantería & $1785<$ \\
\hline LA PEÑA RUIZ SOTILLO, Manuel & Valtierra & 1764 & Teniente general & Infantería & 1802 \\
\hline REMIREZ ESTENOZ, Francisco & Estella & $1680<$ & Coronel & & $1727<$ \\
\hline RENOVALES REBOLLAR, Mariano & Arcentales & 1774 & Brigadier & Caballería & 1808 \\
\hline RIPALDA MARICHALAR, Esteban Joaquín & Gorriz & 1665 & Brigadier & Infantería & 1719 \\
\hline RUIZ PAZUENGOS, Jacinto & Bilbao & 1700 & Mariscal de campo & Caballería & 1776 \\
\hline SADA ANTILLON, Manuel & Tudela & 1677 & Capitán general & Infantería & 1750 \\
\hline SALAZAR EGUILUZ, Eusebio & Vitoria & 1679 & Brigadier & Infantería & 1718 \\
\hline $\begin{array}{l}\text { SALCEDO SIERRALTA, Miguel Eusebio } \\
\text { (conde de Vado) }\end{array}$ & Bilbao & 1748 & Mariscal de campo & Infantería & 1808 \\
\hline SALINAS ALAVA, Diego Felipe & Vitoria & $1685<$ & Mariscal de campo & Infantería & 1709 \\
\hline SANTAMARIA, Pedro & Navarra & $1708<$ & Brigadier & Infantería & 1747 \\
\hline $\begin{array}{l}\text { SARACHAGA GOMEZ DE LA TORRE, } \\
\text { Miguel }\end{array}$ & Bilbao & 1753 & Brigadier & Infantería & 1808 \\
\hline UGARTE, Antonio José & $\begin{array}{l}\text { Valle de } \\
\text { Orozco }\end{array}$ & $1712 \mathrm{c}$ & $\begin{array}{l}\text { Coronel de las milicias de } \\
\text { Guatemala }\end{array}$ & & $1780<$ \\
\hline URANGA AZCUNE, José Ignacio & Azpeitia & 1788 & Brigadier & & 1830 \\
\hline URBINA ORTIZ ZARATE, Luis Francisco & Vitoria & 1721 & Teniente general & Infantería & 1776 \\
\hline URBINA ORTIZ ZARATE, Juan Manuel & Vitoria & 1715 & Brigadier de dragones & & 1760 \\
\hline URRUTIA CASAS, José & Zalla & 1739 & $\begin{array}{l}\text { Ingeniero general de los } \\
\text { ejércitos }\end{array}$ & $\begin{array}{l}\text { Ingeniero/ } \\
\text { infant. }\end{array}$ & 1797 \\
\hline VERTIZ SALCEDO, Juan José & Lesaca & 1723 & Teniente general & Infantería & 1777 \\
\hline VIAL JARABEITIA, Benito & Bilbao & 1730 & Coronel & & $1790<$ \\
\hline $\begin{array}{l}\text { VIANA SAENZ VILLAVERDE, Felipe } \\
\text { Antonio }\end{array}$ & Lagrán & 1739 & Brigadier & Infantería & $1785<$ \\
\hline VIANA SAENZ VILLAVERDE, José Joaquín & Lagrán & 1718 & Mariscal de campo & Infantería & 1767 \\
\hline VIGODET, Gaspar & Sarria & 1764 & Brigadier & & $1810<$ \\
\hline VILLANUEVA ECHARRI, Juan & Pamplona & 1781 & Brigadier & Infantería & 1824 \\
\hline ZABALA VIDARTE, Manuel Fernando & Meñaca & 1788 & Brigadier & Infantería & 1823 \\
\hline ZALDUA GAMBOA, José Ignacio & Bilbao & 1678 & Brigadier & Caballería & 1719 \\
\hline ZALDUA GAMBOA, Antonio Miguel & Bilbao & 1685 & Brigadier & Infantería & 1735 \\
\hline ZALDUENDO, Juan Bautista & Vitoria & 1681 & Mariscal de campo & Caballería & 1745 \\
\hline ZULOAGA MOYA, Gabriel José & Fuenterrabía & 1683 & Teniente general & Infantería & 1741 \\
\hline
\end{tabular}


Oficiales vascos y navarros en la marina, a partir del grado de capitán de navío (siglo XVIII)

\begin{tabular}{|c|c|c|c|c|}
\hline NOMBRE & LUGAR & NAC. & GRADO & FECHA \\
\hline ABAJO HUICI, Carlos José María & Vitoria & 1782 & Capitán de navío & 1826 \\
\hline AGUIRRE ARRANZ, Ventura Ortuño & Vitoria & 1711 & Capitán de navío & 1747 \\
\hline AGUIRRE, José & Munguía & 1711 & Capitán de navío & $1763<$ \\
\hline $\begin{array}{l}\text { ÁLAVA SAENZ DE NAVARRETE, Ignacio } \\
\text { María }\end{array}$ & Vitoria & 1750 & Capitán general de marina & 1814 \\
\hline ARAMBURU URDINOLA, José & Hernani & 1750 & Brigadier de marina & 1802 \\
\hline ARANGUREN ARIZAGA, Francisco & ¿?? & $1719<$ & Capitán de navío & 1747 \\
\hline ARANGUREN GOYENECHE, Miguel & Urnieta & 1716 & Brigadier de marina & 1782 \\
\hline ARRATIA MINER, José & Hernani & 1697 & Capitán de navío & 1740 \\
\hline AYALDE, Tomás & Usurbil & 1761 & Teniente general de marina & 1825 \\
\hline CARASA ERASO, Fermín & Mendavia & 1727 & Brigadier de marina & 1789 \\
\hline CARRANZA VIVERO, Cosme & Trucíos & 1757 & Brigadier de marina & 1815 \\
\hline CARRANZA VIVERO, Juan & Trucíos & 1756 & Capitán de navío & 1802 \\
\hline CHURRUCA ELORZA, Cosme Damián & Motrico & 1761 & Brigadier de marina & 1802 \\
\hline DAOIZ GUENDICA, Fernando & Pamplona & 1739 & Teniente general de marina & 1795 \\
\hline $\begin{array}{l}\text { DIAZ SAN VICENTE OLARTE, José } \\
\text { Francisco }\end{array}$ & Vitoria & 1711 & $\begin{array}{l}\text { Teniente general de la } \\
\text { marina }\end{array}$ & 1779 \\
\hline ECETA, Vicente & Bilbao & 1738 & Jefe de escuadra & $1808<$ \\
\hline EGUIA RAMIREZ ARELLANO, Manuel & Pamplona & 1726 & Jefe de escuadra & $1789<$ \\
\hline ESCUDERO, Antonio & Corella & 1688 & Capitán de navío & 1721 \\
\hline EZQUERRA GUIRIOR, José Javier & Tudela & 1756 & Capitán de navío & 1796 \\
\hline GARDOQUI JARABEITIA, José Ramón & Bilbao & 1814 & Jefe de escuadra & 1755 \\
\hline $\begin{array}{l}\text { GASTON IRIARTE ELIZACOECHEA, } \\
\text { Miguel José }\end{array}$ & Errazu & 1716 & Teniente general de marina & 1779 \\
\hline GAZTAÑETA ITURRIBALZAGA, Antonio & Motrico & 1656 & Teniente general de marina & 1720 \\
\hline GAZTAÑETA URDINSO, José Antonio & Motrico & 1717 & Capitán de navío & $1768<$ \\
\hline GAZTELU JAUREGUIZURIA, Juan Antonio & Larrabezua & 1744 & Brigadier de marina & 1795 \\
\hline GONZÁLEZ BASSECOURT, Vicente Fermín & Pamplona & 1721 & Capitán de navío & $1760<$ \\
\hline GONZÁLEZ CASTEJÓN SALAZAR, Pedro & Tudela & 1719 & Teniente general de marina & 1774 \\
\hline GUIRIOR PORTAL, Manuel & Aoiz de Ugarte & 1708 & Teniente general de marina & 1724 \\
\hline GUTIERREZ VARON, Joaquín & Arcentales & 1710 & Brigadier de marina & 1773 \\
\hline HECETA FONTECHA, Bruno & Bilbao & 1741 & Teniente general de marina & 1802 \\
\hline
\end{tabular}




\begin{tabular}{|c|c|c|c|c|}
\hline HECETA FONTECHA, Vicente & Bilbao & 1733 & Teniente general de marina & 1809 \\
\hline HIDALGO CISNEROS SEIJAS, Francisco & Elorrio & 1721 & Teniente general de marina & 1789 \\
\hline IBÁÑEZ RENTERÍA, José Vicente & Lequeitio & 1699 & Capitán de navío & 1745 \\
\hline IDIAQUEZ BORJA, Agustín & EchaguenAramayona & 1701 & Jefe de escuadra & 1760 \\
\hline ITURRIAGA AGUIRRE, José & Azpeitia & 1699 & Jefe de escuadra & 1753 \\
\hline ITURRIAGA AGUIRRE, Agustín & Azpeitia & 1703 & Capitán de navío & 1740 \\
\hline JABAT AZTAL, Juan Gabriel & Ochagavía & 1768 & Jefe de escuadra & 1820 \\
\hline LANDECHO ALLENDE SALAZAR, Juan & Bilbao & 1737 & Brigadier de marina & 1780 \\
\hline LASTARRIA SAGARRAGA, Francisco & Mundaca & 1697 & Jefe de escuadra & 1760 \\
\hline LEIZAUR AGUIRRE, José & San Sebastián & 1740 & Capitán de navío & $1789<$ \\
\hline LETONA LANDAZURI, Juan José & Elejabeitia & 1756 & Capitán de navío & 1791 \\
\hline LEZO OLABARRIETA, Blas & Pasajes & 1689 & Teniente general de marina & 1734 \\
\hline LORENZO GOICOECHEA, José & Aya & 1711 & Brigadier de marina & 1794 \\
\hline MAGUNA ECHEZARRETA, Joaquín & Ibarruri & 1722 & Capitán de navío & 1769 \\
\hline MAZARREDO GORTAZAR, José & Bilbao & 1745 & Teniente general de marina & 1789 \\
\hline MENDIZABAL BILDOSOLA, Ignacio & San Sebastián & 1728 & Capitán de navío & $1781<$ \\
\hline MONTERO ESPINOSA IZU, José & Pamplona & 1727 & Brigadier de marina & 1789 \\
\hline MONTERO ESPINOSA, José Ignacio & Pasajes de San Juan & 1703 & Capitán de navío & 1747 \\
\hline MULLER WIDENRECH, Gaspar José & San Sebastián & 1753 & Jefe de escuadra de marina & 1814 \\
\hline NOVIA SALCEDO ARANA, Román & Bilbao & 1736 & Capitán de navío & $1790<$ \\
\hline OLAETA ALLENDE, Ignacio María & Guernica & 1755 & Jefe de escuadra & 1814 \\
\hline ROMARETE SALAMANCA, Jacinto & Sodupe & 1775 & Brigadier de marina & 1815 \\
\hline SADA ANTILLON, Miguel (Conde de Clavijo) & Tudela & $1675 \mathrm{c}$ & Teniente general de marina & 1734 \\
\hline SAENZ LAGUARDIA, Pedro & Moreda de Álava & 1758 & Jefe de escuadra & 1829 \\
\hline SALAVERRIA ARIZABALA, Juan Ignacio & Pasajes & $1700<$ & Capitán de navío & 1751 \\
\hline SALAVERRIA ARIZABALA, Juan José & Pasajes & 1723 & Brigadier de marina & 1780 \\
\hline SALAZAR SALAZAR, Luis María & Vitoria & 1758 & Capitán de navío & 1802 \\
\hline SALCEDO ARANCO, José Justo & Portugalete & 1753 & Teniente general de marina & 1805 \\
\hline SESMA ESCRIBANO, Alberto & Tudela & 1756 & Brigadier de marina & 1796 \\
\hline SESMA PAYAN, Fermín & Corella & 1740 & Jefe de escuadra & 1794 \\
\hline $\begin{array}{l}\text { UMENDIA HERQUICIA ESQUERRA, } \\
\text { Francisco }\end{array}$ & Tolosa & 1742 & Brigadier de marina & 1795 \\
\hline ZABALA ARAMBURU, José Martín & Villafranca & 1744 & Brigadier de marina & 1789 \\
\hline
\end{tabular}




\section{Anexo 2}

Diagrama 1. La familia Idiáquez en las Guardias Reales y el ejército.

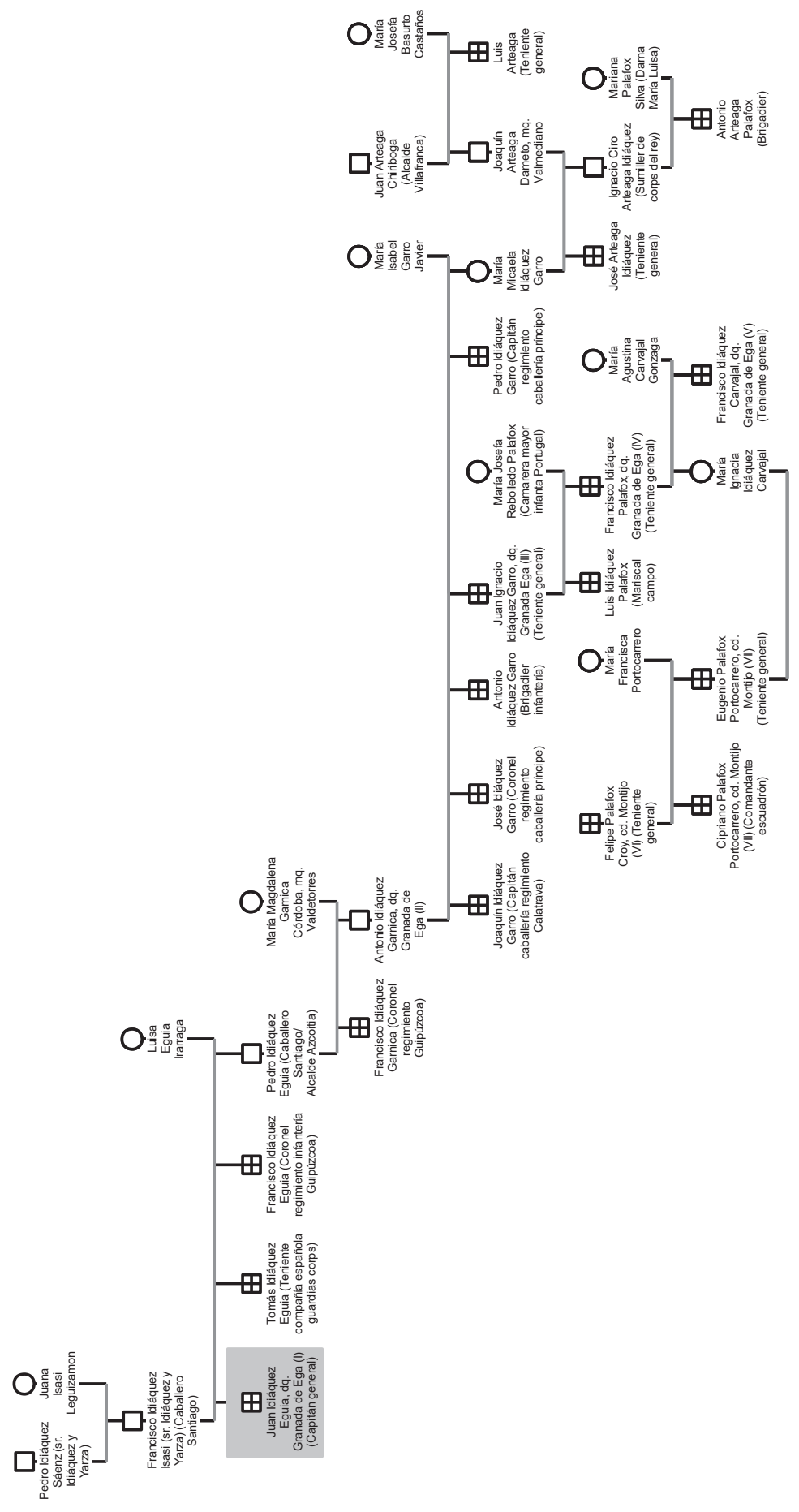


Diagrama 2. La parentela Ruiz de Apodaca en la marina y el ejército (versión reducida)

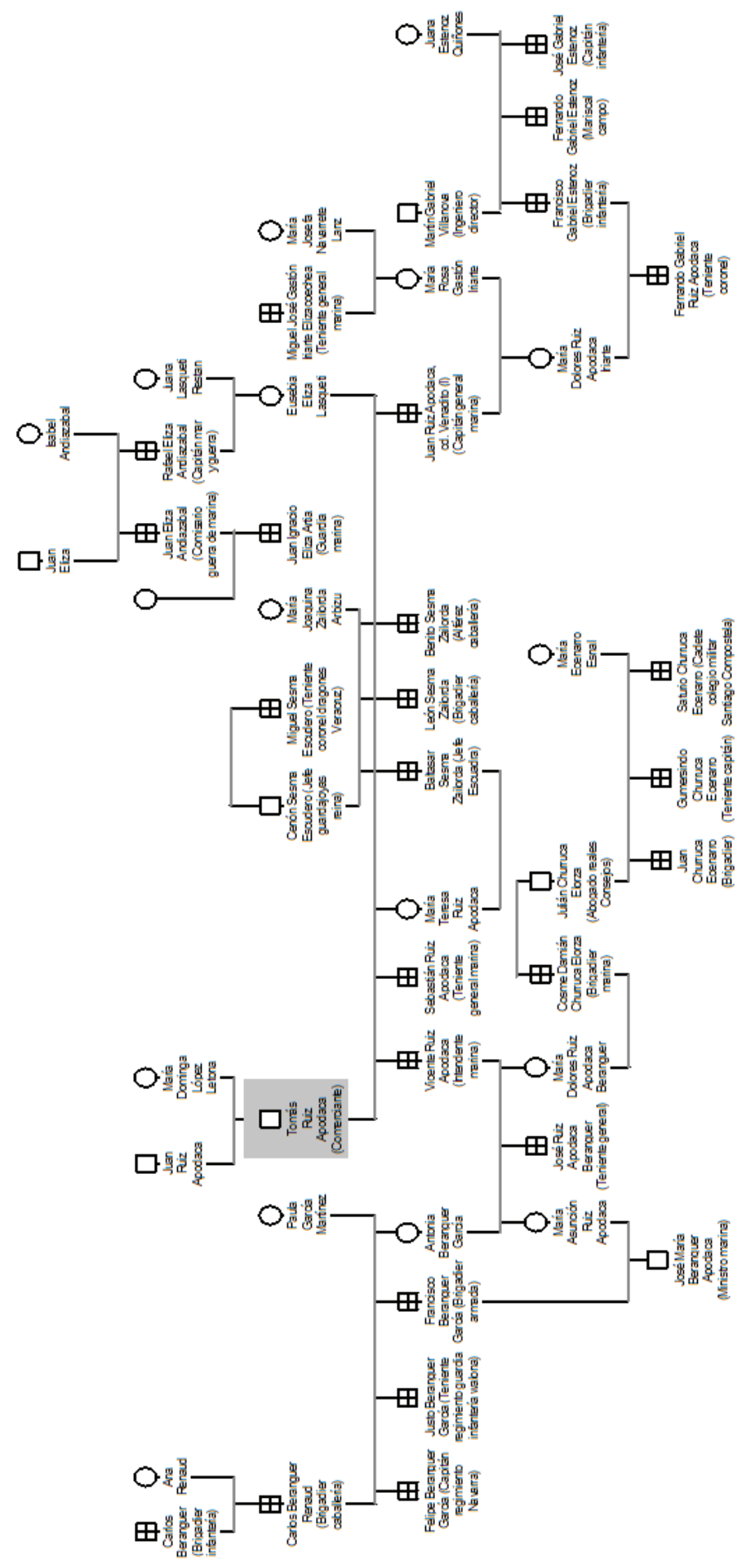


Diagrama 3. La parentela Mazarredo en la marina y el ejército.

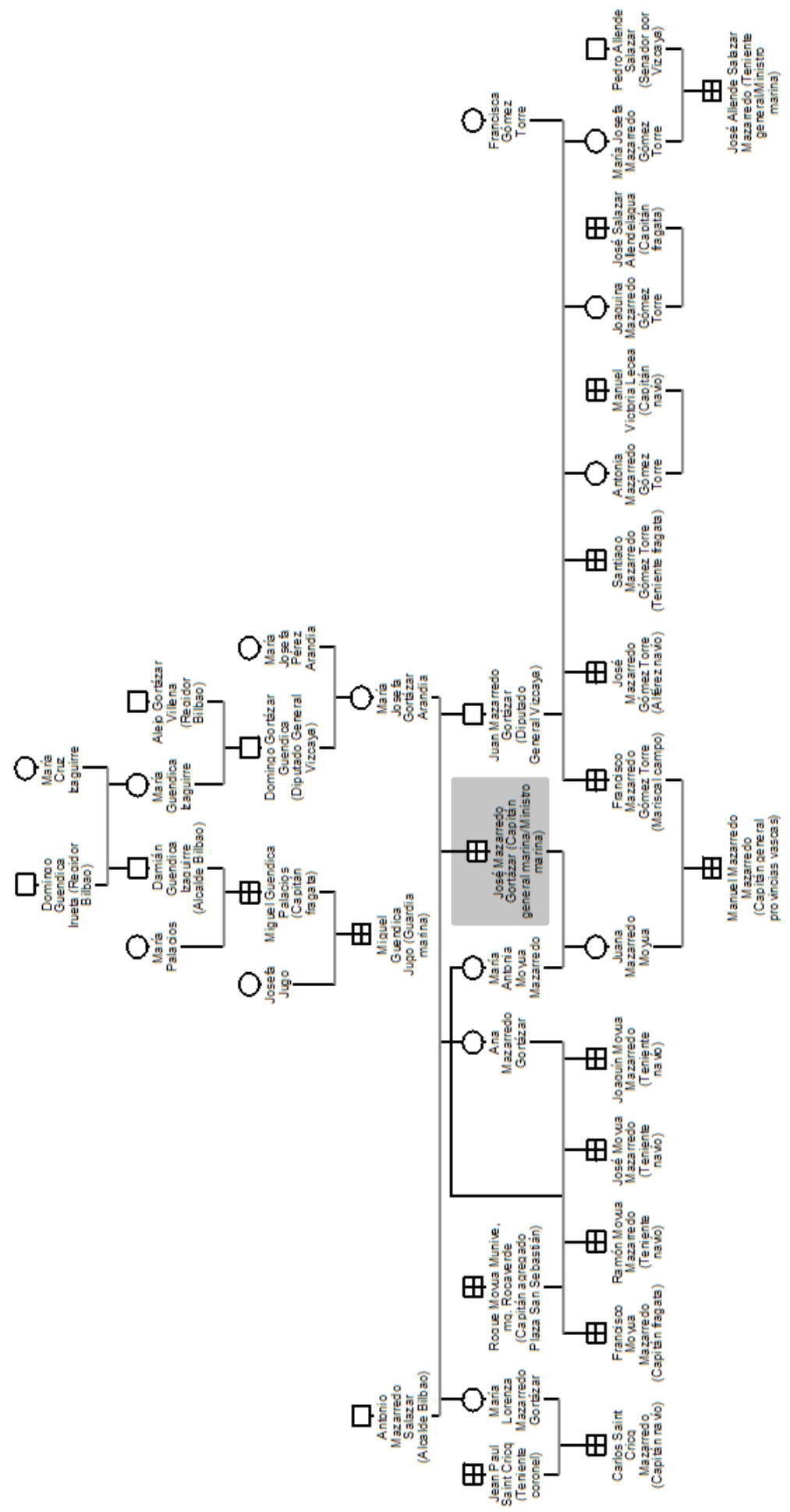


Diagrama 4. La parentela Gastón de Iriarte en el ejército y la marina (visión reducida).

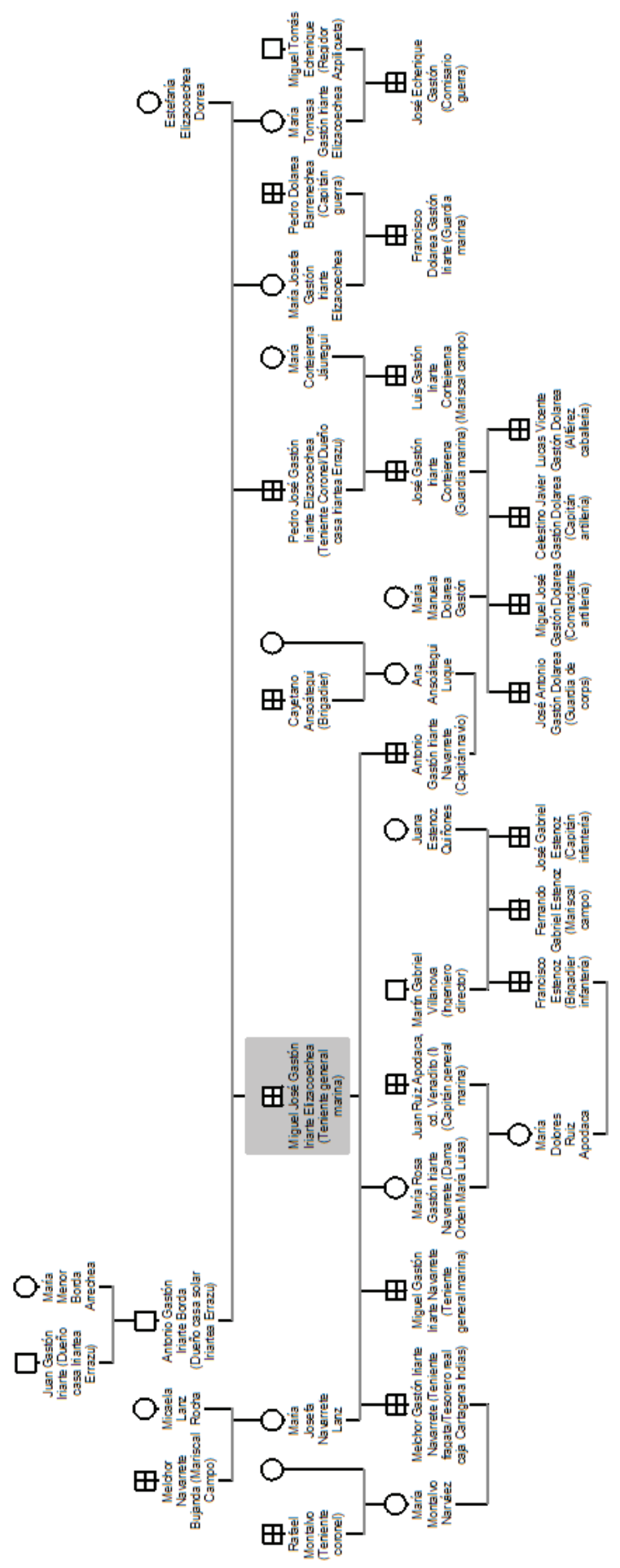


Diagrama 5. La parentela Las Casas en el ejército y la marina.

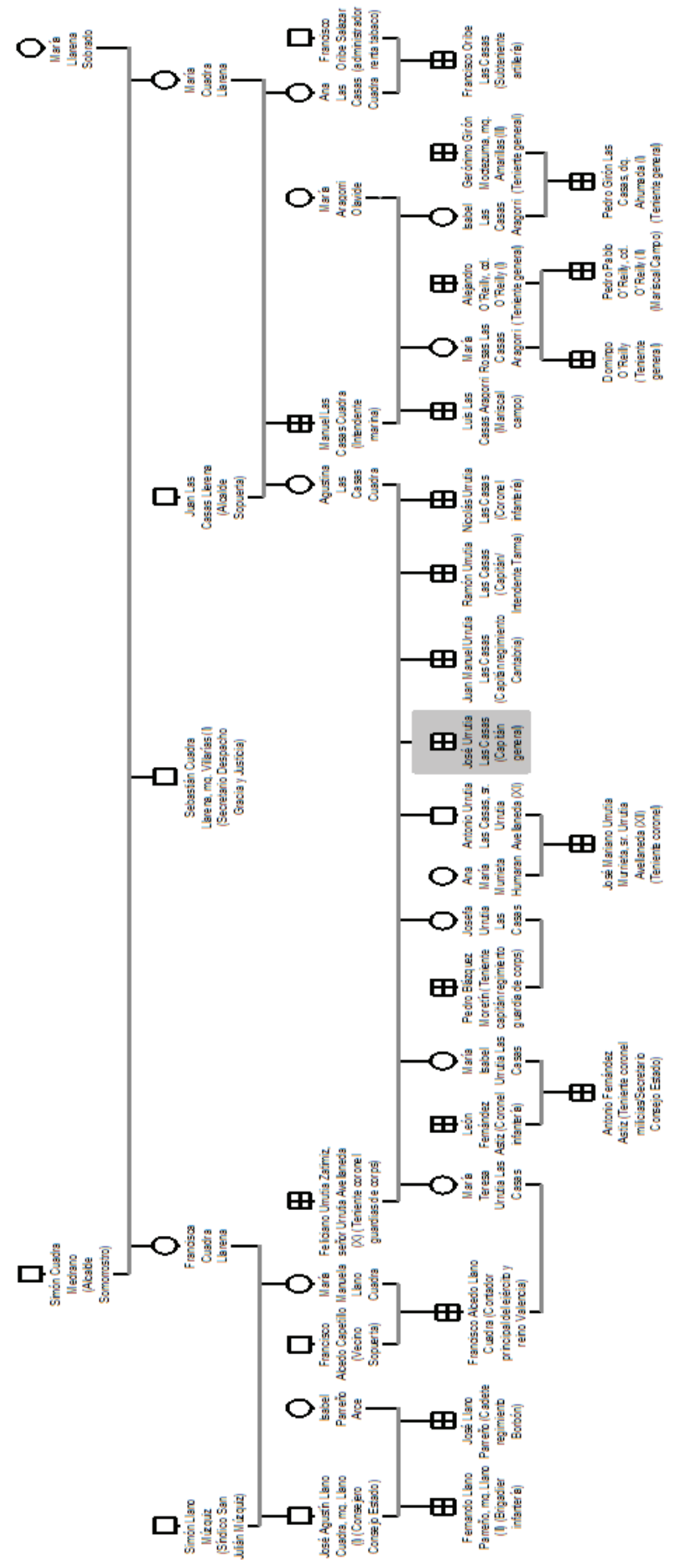

